\title{
TTR
}

Traduction, terminologie, re?daction

\section{Common Sayings and Expressions in Kafka}

\section{Hartmut Binder}

Volume 5, numéro 2, 2e semestre 1992

Kafka pluriel : réécriture et traduction

URI : https://id.erudit.org/iderudit/037123ar

DOI : https://doi.org/10.7202/037123ar

Aller au sommaire du numéro

Éditeur(s)

Association canadienne de traductologie

ISSN

0835-8443 (imprimé)

1708-2188 (numérique)

Découvrir la revue

Citer cet article

Binder, H. (1992). Common Sayings and Expressions in Kafka. TTR, 5(2), 41-105. https://doi.org/10.7202/037123ar d'utilisation que vous pouvez consulter en ligne.

https://apropos.erudit.org/fr/usagers/politique-dutilisation/ 


\section{Common Sayings and Expressions in Kafka}

\section{Hartmut Binder}

Translation by Iris and Donald Bruce, University of Alberta

"Bild, nur Bild"1 [Images, only images]

Proverbial sayings are pictorially formed verbal phrases ${ }^{2}$ whose wording, as it has been handed down, is relatively fixed and whose meaning is different from the sum of its constituent parts. As compound expressions, they are to be distinguished from verbal metaphors; as syntactically dependant constructs, which gain ethical meaning and the status of objects only through their embedding in discursive relationships, they are to be differentiated from proverbs. These appear

1. Franz Kafka, Hochzeitsvorbereitungen auf dem Lande und andere Prosa aus dem Nachlaß, ed. by Max Brod (Frankfurt/M., 1953), p. 349 (henceforth indicated by $\mathrm{H}$ and page).

2. Harald Burger, Idiomatik des Deutschen (Tubingen, 1973), p. 27; and Lutz Rohrich, "Einleitung," in L.R., Lexikon der sprichwörtlichen Redensarten, Band 1 (Freiburg, Basel, Wien, 1973), p. 17: "Because of their imagistic qualities, proverbial sayings are the opposite of abstractions." 
as independent sentences which attempt to instruct about clearly defined situations or to impart moral judgements.

If we take proverbial sayings in a narrower sense, they designate situations which have become incomprehensible as the result of historical distance and changed social structure. Since their meaning has become metaphorical in the course of time, this meaning must be learnt through the use which other speakers make of them. ${ }^{3}$

Phrases of this kind, which primarily bear upon medieval and early-modern warfare, hunting, the practice of law, as well as commerce and the trades, are the exception in Kafka's texts. That is, they appear only when the custom or the practice to be illustrated was still alive, or at least familiar. In The Castle, for instance, one can identify the proverbial saying "jemandem auf den Leim gehen" [to fall into the trap $^{4}$ because Kafka was still conscious of the bird-hunting technique which used glue-covered staves and particularly because the semantic shift to 'fly-catchers' suggested itself, since they made use of the same technique: in one of his letters to Milena, the knowledge of this practice is taken for granted.

3. The definition draws on characteristics which have been pointed out by Wolfgang Schmidt-Hidding in his article "Sprichwörtliche Redensarten. Abgrenzungen - Aufgaben der Forschung," Rheinisches Jahrbuch für Volkskunde, 7 (1956), pp. 15-20 and 142; by Lutz Rohrig and Wolfgang Mieder in their book Sprichwort (Stuttgart, 1977), pp. 15-20; in Wolfgang Fleischer's Phraseologie der deutschen Gegenwartssprache (Leipzig, 1982); and in Werner Koller's Redensarten. Linguistische Aspekte, Vorkommensanalysen, Sprachspiel (Tubingen, 1977).

4. Das Schloß, p. 317.

5. Cf. Franz Kafka, Briefe an Milena. Erweiterte und neu geordnete Ausgabe, ed. by Jürgen Born and Michael Müller (Frankfurt/M., 1983), p. 165: "You don't know my letter to the father, the shaking of the fly stuck to the glue-covered stave [...]." [Du kennst den Vaterbrief nicht, das Rütteln der Fliege an der Leimrute [...].] 
On the other hand, what is even more typical for his use of language are common sayings ${ }^{6}$ or expressions ${ }^{7}$ which, along with proverbial sayings, are all grouped together by modern linguistics under the heading of idiomatic expressions. These two groups simply cannot be clearly differentiated from one another in structure and usage. ${ }^{8}$

The images which are conjured up by proverbial sayings are dependent on specific practices which have since died out. As a contrast, the situations which are described in the idiomatic expressions are taken from the domain of general human conduct. The inherent meaning is formed with the aid of these immediately imaginable and observable situations: for this reason every speaker can intuitively grasp it, even on a first encounter. ${ }^{9}$

The widely held opinion that common sayings and expressions are, as a matter of principle, subject to clearly defined restrictions in usage has been proven wrong. To be sure, lower class speakers make

6. Cf. Wolfgang Fleischer, Phraseologie, p. 19.

7. Wemer Koller, Redensartem, p. 51f.

8. Wolfgang Fleischer, Phraseologie, p. 125, and Wolf Friederich, Moderne deutsche Idiomatik. Systematisches Wörterbuch mit Definitionen und Beispielen (München, 1966), p. 9: "Idiomatic expressions are expressions whose meaning is different from the sum of the individual meaning of the constituent words."

9. Cf. Werner Koller, Redensarten, p. 16: "The idiomatic meanings of 'to pour oil onto the fire' [Öl ins Feuer gießen], "to examine something closely" [etwas unter die Lupe nehmen], "to put a stop to something" [einer Sache einen Riegel vorschieben], "to make someone trip" [jemandem ein Bein stellen], "to fish in the dark" [im Truben fischen], "to throw someone out" [jemanden vor die Tur setzen], "to reconcile matters" [etwas unter einen Hut bringen] can be explained without much ado because of the underlying images. At the same time it can be said that one attempts to create such a link even when the underlying images are not entirely obvious. More than that, one tries to reconstruct a convincing imagistic basis even in the case of idioms with unknown linguistic components." 
preferential use of phrases and particularly of proverbial sayings as indigenous, image-laden expressions which they do not distinguish from their own verbal creations. The danger here is that the type of unproblematic understanding which is supposed to be achieved through the use of such prefabricated linguistic building blocks will be paid for with impersonal language which takes the form of hollow linguistic shells. Common sayings, as has been said, "betray a certain lack of individuality, a type of collective existence, a tendency towards the formalistic and towards popular clichéd thought. They indicate a lack of individual expression, which makes use of precisely such prefabricated popular models of thought [...]. Proverbial sayings are the rhetoric of the common man. He loves proverbs, particularly the drastic ones, and uses them freely in all speech situations. ${ }^{10}$

This is why written texts often indicate stylistic objections to such use of idiomatic expressions. They are placed in quotation marks, which shows the user's critical awareness; or they are introduced by metalinguistic expressions which make clear that one is dealing with phrases which try to reduce everyday situations and solutions to problems to generally accepted formulae. ${ }^{11}$

An example of this technique of presenting an expression as a quotation can be found in Kafka's The Trial. Here the lawyer who is representing $\mathrm{K}$. before the court says the following about the further development of the trial: if all the steps which he had undertaken produced the expected results, "the whole thing would be, as the surgeons say, a clean wound and one could confidently await the outcome" ["sei das Ganze, wie die Chirurgen sagen, eine reine Wunde und man könne getrost das Folgende erwarten"]. ${ }^{12}$

10. Lutz Röhrich, "Introduction," Lexikon der Sprichwörtlichen Redensarten, p. 33.

11. These are expressions such as: "quasi" [quasi], "as they say" [wie man so sagt], or "as it were" [gewissermaßen].

12. Franz Kafka, Der Proceß, edited by Malcolm Pasley (Frankfurt/M., 1990), p. 164 (henceforth: P). (Critical edition.) 
But one should not conclude from this that common sayings and expressions are not a normal feature of oral communication. Rather, they can be used in the oral domain to produce particular nuances of expression, in order to vividly heighten the components of graphic description and to transport the emotional involvement of the speaker by means of their expressivity. ${ }^{13}$ Earlier linguistic research held that proverbial sayings are limited to colloquial speech. This statement is convincing only if one goes back to the regularities that operate in written discourse, for here indeed greater restrictions in phrase usage can be observed. ${ }^{14}$

But even where the standards of literary language are required, common sayings and expressions can be used if the stylistic side-effects of this usage are deemed appropriate or are even expressly desired. ${ }^{15}$ While in scientific language image-laden phrases serve primarily to liven up discourse, ${ }^{16}$ in current affairs and advertising they are frequently used for manipulation. For instance, by consciously going back to outmoded stock phrases one can bring about an ironic alienation effect and the negative evaluation of a situation. ${ }^{17}$

The use of common sayings and expressions in Belles-Lettres should be seen in a similarly differentiated manner. In popular literature they help to provide simple interpretive models and narrative signals. Thanks to their immediately self-evident meaning they are not questioned and the reader is absolved of strenuous analytical deconstruction. In the plays by Franz Xaver Kroetz these linguistic

13. Wolfgang Fleischer, Phraseologie, p. 222: "The use of phrases can underline the effect of an argument through vividness and impressive quality, through the emotional accentuation of an opinion."

14. Ibid., pp. 202-208 and Werner Koller, Redensarten, pp. 55-69.

15. Wolfgang Fleischer, Phraseologie, p. 224.

16. Ibid., pp. 226-228.

17. Ibid., p. 221. 
shells are used to express that the characters are victims of social stereotypes. ${ }^{18}$

Above all, fragmentary or transformed common sayings and expressions, of which there are many in contemporary German literature, offer the possibility for semantic density, for artistic wordplay, and for mutual illumination of language usage as well as of the object of language. This cannot be achieved by lexical elements alone. $^{19}$

Kafka's use of idiomatic expressions in his personal and fictional writings enriches these possibilities through further variations which are worthy of separate analysis.

\section{Autobiographical Writings}

In one of Kafka's letters to Max Brod from 1917 a proverbial saying appears in greatly transformed wording. Kafka says that upon rereading Brod's play he had grasped its artistic character less than on his first reading; however, he had come to understand its implications for the author more correctly, that is, he had come to appreciate it more:

What I mean is, I did grasp it earlier, like something you pick up by the handle, that is as a piece of art, but I didn't grasp it in its entirety. [Ich meine damit: ich faßte es auch fruher, etwa so wie man etwas am Henkel faßt, als Kunstwerk also, aber ich umfaßte es nicht. $]^{20}$

The expression "to grasp the pot by the handle" [den Topf beim Henkel fassen] is used as an aid to formulation, though it is not directly stated. The expression is supposed to indicate that one will deal with the matter in an appropriate fashion if one draws upon the

18. Werner Koller, Redensarten, pp. 79-87.

19. Ibid., pp. 197-210 and Wolfgang Fleischer, Phraseologie, pp. 228232.

20. Franz Kafka, Briefe 1920-1924, ed. by Max Brod (Frankfurt/M., 1958), p. 213 (henceforth: $\mathrm{Br}$ ). 
designated aids and devices. Kafka was able to praise the work on this level only because it was so saturated with illustration that he was almost able to "lay his hand upon it." ${ }^{21}$ This type of praise meant for Kafka that he had technically understood the play, that is with the knowledge of a critic, but this had left him without the allencompassing insight into the effects which were associated with its particularity. However, rereading his increasingly existential understanding brought him to see the autobiographical details reflected in his friend's play. Brod had incorporated these in his writing in such a self-tormenting fashion that a thoroughly unhealthy prognosis for his future life could be the only result. ${ }^{22}$

In this example Kafka has taken the everyday act which founds the common saying and transformed it into an analogy. In similar fashion this analogy returns to the senses, as does the original formulation, and it is furthermore to be situated in the original imaginative context. In contrast the following example shows that Kafka initially gives the traditional wording of the saying, but then gives this expression a new direction by supplementing its content:

Of course I knew what you were going to write, you have already intimated it often enough, have often enough attempted to slip out of the noose, which isn't really one, but rather - now, in any case I will try to hang on to this noose with all my teeth, should you intend to loosen it. [Natuirlich wußte ich ganz genau, was Sie schreiben wurden, Sie haben es oft genug schon angedeutet, oft genug schon den Versuch gemacht, sich aus der Schlinge zu ziehn, die aber gar keine Schlinge ist, sondern nur - nun, jedenfalls werde ich diese Schlinge mit allen Zähnen festzuhalten suchen, falls Sie sie losen wollten.] $]^{23}$

21. Franz Kafka, Briefe an Felice und andere Korrespendenz aus der Verlobungszeit, ed. by Erich Heller and Jürgen Born (Frankfurt/M., 1967), p. 317 (henceforth: F).

22. Cf. Hartmut Binder, "Kafkas literarische Urteile. Ein Betrag zu seiner Typologie und Asthetik," Zeitschrift für deutsche Philologie, 86 (1967), especially pp. 245-248.

23. F 552 . 
The passage which follows this anacoluth shows clearly to what extent even a writer like Kafka at times works with prefabricated building blocks. First of all he supplements the referential domain of the proverb "to pull one's head (or oneself) out of the noose" [sich den Kopf aus der Schlinge ziehen] with another image. By momentarily questioning the validity of the original wording, the referential domain is thrust forward as a real situation. However, at the same time Kafka departs from the original image because he mixes it with a common element which derives from other referential domains. When he writes in his letters and diaries that he is holding something between or with his teeth, chews something up between them or bites hold of something, then such statements testify to the existence of a solid if linguistically changeable conceptual framework which itself in return derives from the phrase "to clench one's teeth" [die Zahne zusammenbeißen]. ${ }^{24}$ The protagonist in the late story The Burrow, for instance, uses this phrasing in order to characterize his own behaviour. ${ }^{25}$

The new context manifested itself, as it were, by means of association. It lay there ready like a linguistic coin and could be used for the fierce resistance which Kafka intended to put up against his epistolary partner Grete Bloch in a very particular matter. In this case the desire to more accurately live up to an object in mind, which was in need of concretization, had led to the mixing of the metaphorical context of these proverbial sayings with images derived from additional expressions. However, the following examples show how phrases can be changed without additions. One reason for resisting traditional linguistic coinings was the fact that they could be experienced as "worn" and "smooth," as if they "had been laid waste by too much

24. Franz Kafka, Briefe an Milena, pp. 26 and 196; F 267 and 445; $\mathrm{Br}$ 174 and 386, as well as F.K., Tagebücher, ed. by Hans-Gerd Koch, Michael Müller and Malcolm Pasley (Frankfurt/M., 1990), p. 770 (henceforth T). (Critical edition.)

25. Franz Kafka, Beschreibung eines Kampfes. Novellen, Skizzen, Aphorismen aus dem Nachlaß, ed. by Max Brod (Frankfurt/M., 1954), p. 192. 
speech," as Werfel says in his early poem, "Pity for a few Words" [Mitleid mit manchen Worten]. ${ }^{26}$

One possibility for renewing worn out linguistic shells consists in transforming the linguistic form and thereby changing and alienating their figurative background. The expression still glows through as background so that one can speak of a shortened quotation, sometimes even of a mere allusion to a corresponding figurative domain. Thus, in an aphorism from the "He" [Er] series (1920) the main character's strained existence is said to stem from the fact that the necessary prerequisites for leading a full life would even then not be there, if one had all the time one needed for it, because the necessary tasks in this context are unknown beforehand:

For this reason he's long been under the wheels; strangely enough or maybe it is a comfort, that is what he was least prepared for. [Deshalb ist er auch schon längst unter den Rädern, merkwlirdigeroder auch tröstlicherweise war er darauf am wenigsten vorbereitet.] ${ }^{27}$

The punch line of this statement lies in the fact that the person concerned does not have to reproach himself for having been thrown off course because he was able to prepare himself just as little for the unforeseeable disaster as for any other event. The expression "to be under the wheels" [unter den Rädem sein] can easily be interpreted as meaning 'being run over' and this, in turn, can be seen as final failure. This is possible only because the expression is understood as a transformation of the proverbial saying "to fall under the wheels" which can be dated back to the middle of the last century. To be sure, this is not to be understood only in the sense of "ethical failure" as

26. Franz Werfel, Das lyrische Werk, ed. by Adolf Klarmann (Frankfurt/M., 1967), p. 57. (The poem appeared in the collection Der Weltfreund, printed in 1911.)

27. Franz Kafka, Beschreibung eines Kampfes, p. 291; cf. T 806, where Kafka mentions he wants "to put on blinkers" [Scheuklappen anziehn] (the proverbial saying goes "to attach blinkers" [Scheuklappen anlegen]). 
documented in Lutz Röhrich's Lexikon der sprichwörtlichen Redensarten, but also in the meaning which Kafka takes for granted. ${ }^{28}$

The changes in wording and meaning which Kafka undertakes in traditional expressions can make the phrases linking him to tradition unrecognizable. When his Metamorphosis was seen by some reviewers as being something pre-eminently German but by others as a very Jewish document, he explained this fact to Felice Bauer in the following manner: "Am I a circus rider on two horses?" [Bin ich ein Zirkusreiter auf 2 Pferden? ${ }^{29}$ The fact that he was obviously an admirer of the circus and used the impressions which he garnered there for literary creation - for example in the prose text At the Gallery [Auf der Galerie] - could lead one to see a direct connection between the representation and the experiences of the author. In this case one could imagine two show horses running in unison next to each other in a circle, on whose backs an artist stands, legs spread wide, and whose art consists in not losing his balance. But where is the third comparison which could lead from here to the opposed ideological interpretations which various commentators claim to have seen in Kafka's stories?

The metaphor can be grasped best only when one recognizes that Kafka has taken as models the proverbs "to be at home in many saddles" [in vielen Sätteln gerecht sein] and "to ride in two saddles" [auf zwei Sătteln reiten]. These arise in the associative game of the mind because he has always used the connection between horse and rider in order to illustrate the conditions under which his literary creation took place..$^{30}$ Due to their inherent figurativeness, these expressions seemed to be able to illustrate the very capacity which he probably had to ascribe to himself on account of these conflicting reviews. Only when he took these expressions literally in order to transform them into textual action did he make use of his circus

28. Cf. Lutz Rohrich, Lexikon der sprichwörtlichen Redensarten, Vol. 3, p. 757 .

29. F 720 .

30. Cf. Franz Kafka, Der Proceß. Apparatband, edited by Malcolm Pasley (Frankfurt/M., 1990), pp. 119-121. 
experience which, in turn, had long since become part of his work in the form of smoothly coordinated associative links ${ }^{31}$ and thus produced the artist who balances on two horses.

Kafka's technique of transforming idiomatic expressions is founded on common usage. In this usage it is not unusual to find formal deviations from the original that occur occasionally as well as through habit. These deviations appear in the form of changes to syntax and morphology as well as through exchange, reduction or expansion of the component elements. The stability of a phrase is not an absolute quantity; rather it possesses a certain degree of variability. ${ }^{32}$ The considerable extent, however, to which Kafka exploits this possibility was quite likely influenced by the dominant linguistic relationships of his homeland.

It is not very likely that the expressions that were used by the German population of Prague were transmitted to him only in oral form. It is rather more likely that his knowledge and understanding of these expressions are equally derived from the norms of written language. Above all they are to be found in literary works in which the play of forms and the citational character of sayings and idiomatic expressions is strongly revealed.

The city in which he grew up and learned to speak had no substantial German lower classes which could have provided him with the intuitive experience of traditional sayings and expressions. Therefore in this respect he had to depend primarily upon his father, who came from modest circumstances, and upon his uneducated mother. Because

31. Cf. Walter Bauer-Wabnegg, Zirkus und Artisten in Franz Kafkas Werk. Ein Beitrag über Körper und Literatur im Zeitalter der Technik (Erlangen, 1986), particularly pp. 56-96, H 302, 304, 325, 393 and T 718.

32. Wolfgang Fleischer, Phraseologie, p. 209f. 
of their Jewish background, however, both parents had a fractured relationship to German culture and its forms of linguistic expression. ${ }^{33}$

German popular imagery was repressed in day to day speech due to the linguistic war which the Prague Jews had to wage on two fronts. On the one hand, living in the Bohemian metropolis one attempted painfully to avoid any deviation from the linguistic rules of middle-class norms. ${ }^{34}$ This tendency was clearly stronger here than in the rest of the German-speaking world. Thus one attempted to eradicate coarse or vulgar language, that is, types of language which were strongly idiomatic. Popular language of this time was always suspicious to Kafka's contemporaries because it was suspected of being influenced by Czech. Anxiously concerned about their own national self assertion, they rejected Czech out of animosity and ingnorance. ${ }^{35}$ On the other hand people tended towards assimilation into German culture and they fought any hint of jargon in intonation and expression, just as they fought fixed expressions typical of Yiddish. ${ }^{36}$ However, by doing this

33. Cf. Bohemia, 90, No. 284 (Oct. 16, 1917), p. 3 and note 164 of this article.

34. In a little fragment from the later period the main character is annoyed about children who, on the steps of a church, are wasting their time "as if on a playground and call each other dirty names, which they cannot understand of course and which they utter only because they do not have anything better to do" (H 327f) [wie auf einem Spielplatz herumtreiben und unanständige Redensarten einander zurufen, die sie natülich nicht verstehen können und an denen sie nur saugen, da sie nichts Besseres haben].

35. Anonymous: "Quod liced Jovi...," Prager Tagblatt, 27, No. 190 (July 12, 1902), p. 3.

36. Cf. T 360f: "Eastern European Jewish habit of inserting phrases like 'my dear ladies and gentlemen' or just 'honourable guests' when speech comes to a halt. [...] As much as I [...] know Löwy, I think he uses such phrases (of which there are many in common Eastern European Jewish talk, such as 'Woe is me!' or 'That's nothing' or 'There's a lot to talk about') not to cover up for embarrassment; rather, these expressions are supposed to function as springs gushing 
they partly rejected traditional imagery which was rooted in the German language as well. ${ }^{37}$

One of Kafka's letters (April, 1917) to his favorite sister Ottla ends with the following words which refer to a little house in central Prague which they both used as a retreat: "And keep your head up, as people say in our street" [Und Kopf hoch, wie man in unserer Gasse sagt]..$^{38}$ Here the writer uses a so-called communicative formula, ${ }^{39}$ but in ironic refraction. Taken literally the observance of this injunction would mean that the physically taller occupants of these tiny houses, like Kafka himself, would hit their heads when crossing the threshold. In reality, every time they entered or left the house they had to remember to stoop, that is, to lower their heads, in order to prevent injury. And it is precisely of this that they tried to remind themselves,

around the current of speech which is still far too slow for the Eastern European Jewish temperament." [Ostjudische Gewohnheit, wo die Rede stockt, 'meine verehrten Damen und Herren' oder nur 'meine Verehrten' einzufügen. [...] So weit ich [...] Löwy kenne glaube ich $\mathrm{da} B$ solche ständige Wendungen, die auch im gewöhnlichen ostjudischen Gespräch oft vorkommen wie 'Weh ist mir!' oder 'S' ist nischt' oder 'S'ist viel zu reden' nicht Verlegenheit verdecken sollen, sondern als immer neue Quellen den für das ostjüdische Temperament immer noch zu schwer daliegenden Strom der Rede umquirlen sollen.]

37. Cf. H 444 and Christoph Stölzl, Kafkas böses Böhmen. Zur Sozialgeschichte eines Prager Juden (München, 1975), p. $27 \mathrm{f}$.

38. Franz Kafka, Briefe an Ottla und die Familie, edited by Hartmut Binder and Klaus Wagenbach (Frankfurt/M., 1974), p. 34.

39. According to Willy Sanders, Linguistische Stilistik. Grundzüge der Stilanalyse sprachlicher Kommunikation (Göttingen, 1977), p. 98, we are dealing here with "fixed phrases, remarks, exclamations, which language provides us with for certain situations, ready for use." 
when they ironically used the opposite form instead of the required one as a slogan, thereby imitating the technique of popular jokes. ${ }^{40}$

Even though Kafka's injunction testifies to the fact that the communicative formula became known to him through the linguistic environment, he also found it in literary contexts. One example that can stand for many is the novel The Great Risk [Das Große Wagnis] by his closest friend Max Brod. ${ }^{41}$

Something similar can be said of the expression "to let one's head hang" [den Kopf hängen lassen]. When Kafka speaks to Felice about a day of "hanging his head" [mit Kopfhängen] or reports on his "hanging head condition" [kopfhängerischen Zustand] and describes one of the characters in his story Eleven Sons [Elf Söhne] as a "head hanger" [Kopfhänger], ${ }^{42}$ one could conceivably think that he is transforming the traditional phrase in the usual way. But even in this case these deviations had long since entered the language. Not only did Max Brod in his novel Jewesses [Jüdinnen] (1911) have a female character say she was no "head hanger" [Kopfhängerin], ${ }^{43}$ but the noun which derived from the expression was in common usage far beyond the limits of Prague. ${ }^{44}$

Finally, in this context the expression "to go to pieces" [aus den Fugen gehen] is informative: Kafka uses it twice in a comparatively

40. Wishes in particular are turned into their. opposite in an ironic manner: thus, the skier is sent on his way with the expression 'break your neck and leg.'

41. Max Brod, Das große Wagnis (Leipzig and Vienna, 1919), pp. 286 and 303.

42. F. 331 and 248; and Franz Kafka, Erzählungen, edited by Max Brod (Frankfurt/M., 1952), p. 175 (henceforth: E).

43. Max Brod, Jüdinnen. Ein Roman (München, 1922), p. 95.

44. Cf. Karl Peltzer, Das treffende Zitat. Gedankengut aus drei Jahrtausenden. Nach Stichwörtern geordnet (München, 1957), p. 348. 
conventional manner. ${ }^{45}$ The use of this expression can be shown in other Prague writers as well. With these writers it is transformed in a way that is just as individualistic as is usually the case only with Kafka; Max Brod concretizes the images upon which this expression is based in his novel The Great Risk [Das Große Wagnis]. Franz Werfel even makes it the matrix of a whole poem. ${ }^{46}$

In addition it can be shown that in this linguistic island, separated from the German Empire and the German speaking areas in the North and West of the country, the idiomatic expressions which were used colloquially departed formally from the customary phenotypes. They were not used outside of Prague, ${ }^{47}$ or became popular only later. Who for instance is aware of the fact that Kafka may have wanted to avoid the title Caste Spirit [Kastengeist] for his story $A$ Visit to a Mine [Ein Besuch im Bergwerk] because this term did not

45. F 391, 416 .

46. Max Brod, Das große Wagnis, p. 219; and Franz Werfel, "Das interurbane Gespräch," in F.W., Das lyrische Werk, p. 103. (The poem is from the 1913 cycle "We are" ["Wir sind"].)

47. For the domain of proverbs, an example from Bruno Kisch, Wanderungen und Wandlungen. Die Geschichte eines Arztes im 20. Jahrhundert (Köln, 1966), p. 18: "one doesn't carry a flag [i.e. a ceremonial procession] through entrance ways joining houses" [man zieht nicht mit einer Fahne durch ein Durchhaus]. In Franz Werfel's 1928 novel Der Abituriententag. Die Geschichte einer Jugendschuld (Frankfurt/M., 1990), female characters who belong to the Prague lower classes make use of colloquial expressions which (probably because they were used only in a restricted area of the Danube monarchy) cannot be verified in books on idiomatic expressions and are therefore only approximately comprehensible to the present-day reader: "'My brother is a golden man. He always says: Franz will yet win his head" " ["'Mein Bruder ist ein goldener Mann. Immer sagt er: Der Franz, der wird sich noch den Kopf einnehmen""] (p. 110, cf. p. 118f. and note 137). 
only mean 'pride of place' [Standesdünkel] for his compatriots, but also "prompteur" [Souffleur] ? ${ }^{48}$

When the head porter in America [Der Verschollene] says to Karl: "it wasn't worth my while" [du standst mir natürlich nicht dafür,${ }^{49}$ this expression is derived from an Austrian idiom "(nicht) dafür stehen", still valid today, which means "(not) to be worthwhile". ${ }^{50}$ Furthermore, the expression "to settle something" [einen Weg machen] is found in The Castle [Das Schloß]. But Kafka avoided this expression because it would not have been known to anyone outside of this region. ${ }^{51}$ Similarly, the verb "to hold" [halten] was used in an idiomatic fashion in the sense of "delay" or "to have progressed up to a certain point". 52 Kafka puts it not unintentionally, as will be shown, into the mouth of old Bendemann in The Judgement [Das Urteil]. ${ }^{53}$

As far as the possible variants of traditional expressions in Káfka's home town are concerned, we find the following example in the

48. Cf. H 440 with: Anonymous, "Witze," Prager Tagblatt, 26, No. 118 (April 30, 1902), p. 21.

49. Franz Kafka, Der Verschollene, edited by Jost Schillemeit (Frankfurt/M., 1983), p. 262 (henceforth: A). (Critical edition.)

50. Cf. Egon Erwin Kisch, "Prager Deutsch," Bohemia, 90, No. 282 (Oct. 14, 1917), p. 1f.

51. Compare Franz Kafka, Das Schloß. Apparatband, edited by Malcolm Pasley (Frankfurt/M., 1982), p. 357, where the expression is used in a passage which was later deleted by the author, with America [Der Verschollene], where Kafka has a young girl say twice she had to go shopping [Besorgungen machen] (A 181, 194).

52. Jakob Ebner, Duden. Wie sagt man in Osterreich. Wörterbuch der österreichischen Besonderheiten, 2., vollstăndig überarbeitete Auflage (Mannheim, Wien, Zürich, 1980), p. 88, Franz Kafka, Briefe an Ottla pp. 71, 83 and 117, as well as F 663: "and this is enough for now" [und dabei halten wir jetzt].

53. E 60. 
diaries of the nineteen year old Prague dramatist Paul Kornfeld (these were meant only for personal use and are thus very close to colloquial speech): "I've learned to throw the money." ["Ich habe gelernt, mit dem Geld zu werfen"]. ${ }^{54}$ The correct formulation would have been: "to throw money around" ["mit Geld um sich zu werfen"]. As such it is cited only by Wolf Friederich (and here only as restricted to colloquial speech), who attempts to record those expressions which are presently still in use. ${ }^{55}$ It is not listed in Lutz Robrich, who gives only the expression "to throw the money (with full hands) out of the window" ["das Geld (mit vollen Händen) zum Fenster hinauswerfen"] in order to indicate the notion of the useless waste of money. ${ }^{56}$

We can see that mere deviation from the norm is no warrant for artistic originality, not even if there are reasons that make such transformations of solid word combinations plausible. If Kafka avoids the empty phrase "by means of" ["anhand"], which derives from legal discourse, and instead employs "by the hand" [an der Hand], one might draw the conclusion that this was an attempt to revive the original imagistic content of the preposition. ${ }^{57}$ As a matter of fact the term in question was in common usage in Kafka's environment as a fixed word combination. As such it was employed in legal publications of his

54. Unpublished entry of December 13, 1909. These diary entries are used with the permission of the Deutsches Literaturarchiv in Marbach/N., which is in possession of this work.

55. Wolf Friederich, Moderne deutsche Ideomatik, p. 475.

56. Lutz Röhrich, Lexikon der sprichtwörtlichen Redensarten, Vol. 1, p. 319.

57. See Hartmut Binder, Kafka in neuer Sicht. Mimik, Gestik und Personengefüge als Darstellungsformen des Autobiographischen (Stuttgart, 1976), p. 246f. 
office; publications of this nature are, as everyone knows, notorious for difficult abstract language..$^{58}$

It is certainly not to be ruled out and indeed highly likely that Kafka did see the accompanying hand before his inner eye as he wrote down this expression. It was typical of his particular type of imagination that he could indeed suddenly conjure up the original meaning of lexical images, even if it was not understood in this sense anymore..$^{59}$ At times he proceeds according to principles of popular etymology. This means he links expressions with figurative variants which cannot be substantiated linguistically, ${ }^{60}$ or he deduces concretizations of fixed

58. Cf. Fünfundzwanzig Jahre Arbeiter-Unfall-Versicherung. Bericht über die Entwicklung der Arbeiter-Unfall-Versicherungsanstalt für das Königreich Böhmen in der Zeit vom 1. November 1889 bis 31 . Oktober 1914, ed. by Robert Marschner (Prague, 1915).

59. Cf. $\mathrm{Br} 458$ ("'to drag' and 'to leave a trail behind' remind one too much of crawling caterpillars") and Ludwig Hardt, "Erinnerungen an Kafka," in Die Fähre, 2 (1947), p. 77, where it is reported that Kafka supposedly said, after the recitation of "Eleven Sons" ["Elf Sohne"], that one could literally see the drawn sword upon hearing the word "entzutckt" [it is charming] (The pun is based on the addition of the prefix "ent-", to the verb "zucken." In the expression "ein Schwert zilcken" (to draw a sword) the verb has a literal meaning; the addition of the prefix renders the verb figurative and changes its semantic value. [Translators' note]). Cf. E 172: "it is charming to see him in a fencing position" [es entzulckt, ihn in Fechterstellung zu sehen].

60. Cf. Franz Kafka, Briefe an Ottla, p. 42: "when she [probably the housekeeper of the Kafka family, Marie Werner] opens her eyes in the next room, then the noise awakens me. (The expression 'knock open your eyes' [Augenaufschlagen] must have been invented by a sensitive old German." [wenn sie nebenan die Augen aufschlägt, weckt mich der Lärm. (Den Ausdruck 'Augenaufschlagen' muß auch ein empfindlicher alter Deutscher erfunden haben.)] Kafka is referring to the noise which comes about when someone throws back the bed cover, pulls up the blinds - in Prague houses there were no wooden shutters to be thrown open [aufgeschlagen] - or opens the doors. One can see that he takes the expression literally and as a type of synecdoche. 
word combinations from actions which are only imagined, which have nothing to do with their genesis. ${ }^{61}$

Such imagination is nothing extraordinary, even though it may perhaps stand out particularly in Kafka's case. Ordinary people who are linguistically less educated often experience much more forcefully than intellectuals the sensual component of expressions. Thanks to this these expressions often originate in this group and become widespread. In contrast, intellectuals react in a different fashion to language's inherent possibilities for abstraction. An example of this is the fact that idiomatic expressions in everyday speech can also be used in their literal sense. Often the use of additional lexical items ${ }^{62}$ points out the double meaning which is intended by the speaker. ${ }^{63}$

Other writers as well have this penetrating insight into linguistic phenomena, which recreates the world of appearances represented in them in near original freshness. ${ }^{64}$ For instance, Charles Dickens' eidetic bent translated linguistic concepts immediately into the movement of scenic pictures. ${ }^{65}$ Or let us take Christian Morgenstem whose penchant for puns created absurd situations in that he took literally what presented itself to him as metaphor. ${ }^{66}$

61. Cf. H 88: "Vanity makes someone ugly, should therefore kill itself, but instead it only hurts itself and becomes 'hurt vanity' [verletzte Eitelkeit]." [Eitelkeit macht häßlich, mußte sich eigentlich ertöten, statt dessen verletzt sie sich nur, wird 'verletzte Eitelkeit.']

62. That is, 'literally' or in 'the real sense of the word.'

63. Werner Koller, Redensarten, pp. 13-15.

64. See Wemer Koller for examples: Redensarten, pp. 197-205.

65. Wolfgang Schmidt-Hidding, Sprichwörtliche Redensarten, pp. 132 and 142.

66. Lutz Röhrich, Gebärde - Metapher - Parodie. Studien zur Sprache und Volksdichtung (Dulsseldorf, 1967), p. $207 f$. 
Once loosened, set free from their fixed linguistic form, images can become autonomous and develop according to narrative structure. One example of such a scene which developed out of a phrase can be found in one of Kafka's letters (April, 1921):

Sometimes, for fun, I imagine an anonymous Greek who arrives in Troy even though he never planned to go there. He hasn't looked around yet but he is already in the midst of the action, the Gods themselves do not know what this is all about, but he's hanging from a Trojan chariot and is dragged through the city, it will be a long time until Homer even begins to sing, but he is lying there already with glassy eyes, if not in Trojan dust then in the cushions of a deckchair. [Manchmal stelle ich mir zum Spiel einen anonymen Griechen vor, der nach Troja kommt, ohne daß er jemals dorthin wollte. Er hat sich dort noch nicht umgesehn, ist aber schon im Getümmel, die Götter selbst wissen noch gar nicht, um was es geht, er aber hängt schon an einem trojanischen Streitwagen und wird um die Stadt geschleift, Homer hat noch lange nicht zu singen angefangen, er aber liegt schon mit glasigen Augen da, wenn nicht im trojanischen Staub so in den Polstem des Liegestuhles.] ${ }^{67}$

The inner association with the above cited aphorism, written nearly a year later, is obvious. However, the manner of death of this unwilling fighter is not mentioned and, borrowing on the fate of Hector who perished before the walls of Troy, only the desecration of the dead body is reported. This desecration though seems to re-enact faithfully a variant of the idiomatic expression which is inherent in the other passage: whoever lies dead behind such a vehicle has literally, as it were, come under its wheels whose movement now mutilates him in addition.

In both cases the extent of overburdening seems to be greatly exaggerated, which is in agreement with corresponding passages in the personal writings. These are, however, dependent on other levels of imagery. ${ }^{68}$ Finally, as in the aphorism the task which is to be

67. Br $313 f$.

68. As in T 912: "not even born yet and already forced to walk on the streets and to talk with people." 
completed here is unknown, unforeseeable, because not even the Gods know how quickly the newcomer will be run over by the wheels of fortune.

An already existing structural model, which of course can be illustrated on different imaginative levels, is made into an image here by alluding to a literary heritage deriving from antiquity as well as through the use of a proverbial saying. This saying had been contemporaneous with the writer many years previous and had even been applied by him to his own personal circumstances, the critical analysis of which had engendered the above mentioned conceptual play. For even at the end of August, 1913, Kafka had written to Felice regarding the problematic situation which characterized their relationship:

That you, my dearest, should fall with me beneath the wheels of this wagon which is meant for me alone, that is indeed horrible. [DaB Du, Liebste, mit mir unter die Räder dieses Wagens kommen mußt, der nur fuir mich bestimmt ist, das ist allerdings schrecklich. $]^{69}$

\section{The Novels}

In the novels as well common sayings appear in changed form. There is an interesting example in The Trial where we hear that

if one changes something in one's position by one's own hand, one takes away the ground from under one's feet and risks plunging into the abyss. [wenn man auf seinem Platz selbstständig etwas ändert, den Boden unter den Fußen sich wegnimmt und selbst absturzen kann]. ${ }^{70}$

It is obvious that when he formulated this passage Kafka had in mind the saying "to lose the ground under one's feet" [den Boden unter den Füßen verlieren] which may have suggested itself in an associative fashion: images which were suited to express the likely relationship

69. F 456; compare 347 .

70. P 160. 
between man and the ground which carries him belong to his favorite metaphors. These have taken on the role of common places in his thought. ${ }^{71}$

On the other hand it is equally obvious that Kafka tested conventional word combinations for their semantic values. He must have been dissatisfied with the traditional wording which poorly expressed the contours of the accent which Kafka meant to give and brought out merely one of many connotations: whoever loses the ground under his feet lacks a connection to his natural point of departure, tends as a result towards self overestimation and in this way finally loses his inner stability, whatever this may mean. Kafka imagines this last point graphically, so to speak, draws an obvious conclusion and illustrates it immediately with a verb of his choice.

It is obvious that through this transformation Kafka attempted to bypass the worn out expression without sacrificing its imagery. But here the question arises why in his novels he often uses common sayings in their original form and meaning, that is, without the semantic and formal deviations which are so characteristic of his personal writings and which, for Kafka, are almost the rule. The main reason for this remarkable difference lies in the fact that the phrases which one comes across in his major works are not part of the descriptive or narrative sections, but are placed in the mouth of fictive characters. They are used for characterization and serve as a means to attest to the

71. Cf. $\mathrm{H} 83,318 ; \mathrm{F} 76,203,314$; as well as $\mathrm{Br} 384$. 
linguistic realism of a character. ${ }^{72}$ In many cases this presupposes that they are used in the original sense.

Now, the above example is also related to a character in the novel as an utterance, for it comes from the endless statements in which the lawyer seeks to make clear the role and importance of the defence in the case which has been brought against his client. But these statements which $\mathrm{K}$. mentally goes over again one day in his office are

72. Naturally it is not only sayings and imagistic expressions which can be used in this fashion but all sorts of linguistic commonplaces and colloquial expressions as well. These appear particularly in expressions of official character, as a constituent part of ritual and as set pieces. Once, Kafka himself lost control to such an extent that he burst out laughing when he heard a similarly "schematic imperial speech which was utterly senseless and without cause" by the highest director of his company (F 237-240). Kafka caricatured such discourse vividly in a small fragment: here a representative of the board of directors responds to complaints raised by a spokesman of the employees. He gives the following answer which consists almost entirely of fixed expressions: "Yes, yes, very well [...] yes, your individual and all of your collective requests are most certainly very justifiable, I and the other directors are certainly the last people who would not see that. You must believe me, the well-being of the people is of greater importance to us than the well-being of the company. And why not? The company can always be rebuilt, it costs only money, but when a human being is ruined, then a human being is ruined, there is the widow who remains, the children. Oh, for heaven's sakel For this reason every proposal to put in place new security, new facilities, new comfort and luxuries is very welcome indeed. Whoever proposes any such things is our man." [ Ja, ja, es ist gut es ist gut [...] also deine und eure Bitte ist gewiß berechtigt, ich und die Herren von der Direktion sind gewiß die letzten, die das nicht einsehen wirden. Das Wohl der Leute, glaube mir, liegt uns mehr am Herzen als das Wohl des Werkes. Warum auch nicht? Das Werk kann immer wieder neu errichtet werden, es kostet nur Geld, geht aber ein Mensch zugrunde, so geht eben ein Mensch zugrunde, es bleibt die Witwe, die Kinder. Ach du liebe Güte! Darum ist also jeder Vorschlag, neue Sicherung, neue Erleichterung, neue Bequemlichkeit und Luxuriositäten einzufuhren, uns hochwillkommen. Wer damit kommt, ist unser Mann.] (H 135f) 
not formally expressed as direct speech. Rather, they proceed from formal principles which Kafka has for the most part thought out himself. With their help he attempted to remove the stylistic ponderousness of fourteen pages of indirect speech. ${ }^{73}$ But, precisely because of the coherent and original presentation, this part of the seventh chapter appears not only as the linguistic outline of a narrative figure who lives entirely within the law, but also as an artistically presented specialized prose which can only in part integrate popular images. Apart from the use of metaphor which has already been mentioned in a different context (here we are dealing with a little known phrase from surgical terminology which quite supports the particular stylistic level), there is only one worn out phrase in this whole section, which Kafka has left, however, in its traditional form. ${ }^{74}$

The following passage is to be found at one point in the Trial in a discussion between $\mathrm{K}$. and a factory owner:

"Mr. head clerk," said the factory owner, "you must be suffering from the weather. You look so gloomy today." "Yes", said K. and put his hand to his temple, "Headaches, family troubles." "Yes, indeed" said the factory owner, who was a man in a hurry and had no patience to listen to anyone, "each has his cross to carry." ["Herr Prokurist", sagte der Fabrikant, "Sie leiden wohl unter dem Wetter. Sie sehn heute so bedrickt aus." "Ja", sagte K. und griff mit der Hand an die Schläfe, "Kopfschmerzen, Familiensorgen." "Sehr richtig", sagte der Fabrikant, der ein eiliger Mensch war und niemanden ruhig anhören konnte, "jeder hat sein Kreuz zu tragen".]

The factory owner's commentary on the head clerk's wellbeing serves at the same time to illustrate his character. Since he is not truly capable of understanding the statements of others, his answer can

73. See Hartmut Binder: Motiv und Gestaltung bei Franz Kafka. 2nd edition (Bonn, 1987), pp. 220-231.

74. P 158: "If $K$. were still wondering, if he were able to keep everything in his sight (...)." [Wundere sich K. noch, wern er alles dieses im Auge behalte (...).]

75. P 179. 
only be a commonplace. He raises the New Testament expression "to bear one's cross" [sein Kreuz tragen] to the level of a commonplace and shows that he is indebted to prefabricated thought patterns.

With this aim in mind Kafka has occasionally utilized common linguistic stereotypes in his novel. We are dealing here with so-called proverbial comparisons, and thus fixed non idiomatic structures of comparison. $^{76}$ As popular formulations they have become an inherent part of colloquial speech. Such clichés have become worn out and trivial through constant repetition and because of the simplicity of the imaginative world upon which they are based. They seek to signify by means of emphasis or exaggeration. Thus the relationship between the receiver of the image and the sender is that of a generalizing synechdoche. ${ }^{77}$

Even though the 'how'-comparison is dominant, there are also metaphors which portray what is meant in the manner which I have just described: in derogatory, ironic or exaggerated fashion. For example, in Amerika the tramp and scoundral Delamarche claims that Karl Roßmann is as "quiet as a mouse" [still wie ein Mäuschen] or that he can "run like a horse" [laufen wie ein Pferd]. On the other hand, if he wants to express the arrogant thanklessness of the young hero, he uses the derogatory term "a fine pike" [ein feiner Hecht]. A similar manner of speaking is typical of Delamarche's buddy Robinson, who describes his opponents twice as "dogs" [Hunde], as "lazy buggers" [faule Luder], "grass frogs" [Grasfrosche] and "devils" [Teufel] and regards the singer Brunelda as an object to be licked or drained.

The structural principle of the work is that $K$. later experiences what was done first to others with his participation or tacit permission. This principle has its counterpart in the imagery which is employed. For when Robinson acts in one place "like a watchdog" [wie ein

76. Wolfgang Fleischer, Phraseologie, p. 125.

77. See Jacques Dubois et al., Allgemeine Rhetorik. Trans. and ed. by Armin Schutz (München, 1974), p. 187f. 
Wächterhund] and is treated like a dog by Delamarche, ${ }^{78}$ then the insult which was meant for others, understood literally, falls back on its creator in such a way that it determines his future destiny.

At times we also find proverbial comparisons in the personal writings as in one of Kafka's letters to Felice Bauer (July, 1915):

[...] and this is how I am in the sanatorium. Shameful and consistent, it fits my other life like a top fits on a pot. [und so bin ich im Sanatorium. Schändlich und konsequent, paßt auf mein sonstiges Leben wie der Deckel auf den Topf.] ${ }^{79}$

78. A 164, 212, 268, 280, 286, 299, 303, 311, 312 and 321, compare 295 (where Robinson is woken up with a foot), 299 (where he is hit in the face with a whip) and 298 (where he is "entirely pushed to the side" [ganz bei Seite geschoben ist] like Karl Roßmann (A 7) who, in a symbolic act, "is slowly pushed to the edge of the ship's deck" [allmählich bis ans Bordgeländer geschoben]; Robinson concludes: "if you are always treated like a dog, then you come to think that you are one yourself" [wenn man immerfort als Hund behandelt wird denkt man schlieBlich man ists wirklich].

Cf. Hartmut Binder, Kafka-Kommentar zu den Romanen, Rezensionen, Aphorismen und zum Brief an den Vater. 2nd edition (München, 1982), p. 93 and Karl-Heinz Fingerhut, Die Funktion der Tierfiguren im Werke Franz Kafkas. Offene Erzählgerüste und Figurenspiele (Bonn, 1969), p. 215f.: "His [Robinson's] subservience vis-à-vis Delamarche, his servile lust for Brunelda and his vicious and reckless attitude towards Karl Roßmann are adequately described through the animal metaphor."

Barbara Beutner, Die Bildsprache Franz Kafkas (München, 1973) pp. 58, 85f. and 98, does not understand the function of the metaphors employed by Delamarche and Robinson. This is because she does not consider these elements in relation to the characters and in view of their conventionality but rather evaluates them from the perspective of Kafka's own chosen metaphorical level and classifies them according to types as they are passed on through the rhetoric of antiquity. Beutner and Fingerhut also do not consider that the dog metaphor is slightly differently arranged in each of the three novel fragments.

79. F 641 . 
Even though the underlying expression "to fit together like pot and its top" [wie Topf und Deckel zusammenpassen] is used in a transformation that is not uncommon, the verb (which is used in this figurative and thus non-concrete sense) really requires the preposition "to" [zu]. When Kafka adapts it to the preposition "auf" [on] of the expression, he indicates that he, at this point, imagines the currently existing situation in the form of a pot, as it were. The present stay in the sanatorium is like a crowning event that fits like the top on the pot.

As a rule Kafka avoids grammatical particles used in comparisons, substitutes the fixed source of an image by another, or employs levels of visualization which underlie proverbial comparisons as independent metaphors. Thus the expression "the fist in the eye" [Faustschlag aufs Auge] which derives from the idiomatic phrase "as the fist fits the eye" [wie die Faust aufs Auge passen] merely serves to express metaphorically the brutality of an annoying noise. It does not seek to illustrate the incompatibility of two sets of circumstances, as the idiomatic phrase presupposes, which semantically means the opposite of the fitting together of pot and top. On the same level Kafka avoids the proverbial comparison "sweet as honey" [süß wie Honig] when he attempts to express his innermost feelings and instead uses, it tastes "like honey" [wie Honig] to him. Nor does he let collapse "like a house of cards" [wie ein Kartenhaus] the vain results of outbursts of vanity. Rather he formulates it thus:

Even the futility of a house of cards collapses, if the artist gives himself airs. [Schon das Nichtige eines Kartenhauses fält zusammen, wenn der Künstler sich aufblust. $]^{80}$

In these last two cases Kafka wants to use a common, everyday conception, but not in the common formulation in which it is handed down.

One can place the famous last sentence of The Trial in this context in which the dying head clerk $\mathrm{K}$. thinks over the circumstances of his death with the words:

80. F 311; T 368; and $\mathrm{Br} 196$. 
'Like a dog!' he said, it was as if shame should outlive him. ['Wie ein Hund!' sagte er, es war als sollte die Scham ihn uberleben.] ${ }^{\text {al }}$

The proverbial comparison "to die like a dog" [verrecken (oder krepieren) wie ein Hund] is used, for example, by Max Brod. Kafka encountered it in slightly changed form as a "repeated saying" [stăndige Redensart] of his father's who used to say about a tubercular employee: "He ought to die, the sick dog." [Er soll krepieren, der kranke Hund.] ${ }^{82}$

By abandoning the verb which carries the image as well as the link to the consciousness of the main character, who is incapable of carrying out his own execution which he recognizes as inevitable, the proverbial triviality is removed from the comparison which is presented. This is done without sacrificing the easily remembered formal character of the expression which Kafka wishes to retain.

A contrast of proverbial comparisons and sayings is also instructive. Kafka uses these in his literary texts as well as in his autobiographical texts: ${ }^{83}$

He himself had known people who had just arrived. Instead of acting according to these good principles they had stood on their balcony for days looking down onto the street like lost sheep. (The uncle speaking to $\mathrm{Karl}$ in America.) [Er selbst habe Neuankömmlinge gekannt, die z. B. statt nach diesen guten Grundsätzen sich still $\mathrm{zu}$ verhalten, tagelang auf ihrem Balkon gestanden und wie verlorene Schafe auf die Straße heruntergesehen hätten. (Der Onkel zu Karl im Verschollenen)

I am more insecure than I ever was before. The only thing I feel is the force of life. And I'm meaninglessly empty. I am really like a lost

81. P 312.

82. H 186; cf. Max Brod, Das große Wagnis, p. 264: "Without a little viciousness, you'll kick the bucket on the spot. Like a dog." [Ohne Bösartigkeit verreckt man auf der Stelle. Wie ein Hund.]

83. The following passages are to be found in A 56; T 594; S 134f; and F 197. 
sheep in the night and in the mountains or like a sheep that is running after the first sheep. To be so lost and not to have the energy to deplore this condition. (Diaries) [Ich bin unsicherer als ich jemals war, nur die Gewalt des Lebens fühle ich. Und sinnlos leer bin ich. Ich bin wirklich wie ein verlorenes Schaf in der Nacht und im Gebirge oder wie ein Schaf, das diesem Schaf nachläuft. So verloren zu sein und nicht die Kraft haben, es zu beklagen. (Tagebücher)

But besides, I believe in the hope that the good star that has led you to Klamm - provided that it was a good star, but you insist that it was - this good star belongs to you, that it must stay with you, and will not leave you so fast and suddenly as Klamm has done. (The Land Surveyor to the innkeeper in The Castle). [Außerdem aber, glaube ich, die Hoffnung, daß der gute Stem, der Sie zu Klamm gefuhrt hat - vorausgesetzt, da $B$ es ein guter Stern war, aber Sie behaupten es - zu Thnen gehöre, also bei Ihnen bleiben mulsse und Sie nicht etwa so schnell und plötzlich verlassen werde, wie Klamm es getan hat. (Der Landvermesser im Schloß zur Brickenhofwirtin)]

When I read it [the old letter from the beginning of our relationship which I never sent] then I see amidst other mad hopes [...] that everything has become so much more beautiful and that one would like to believe that the good star that has guided us will never be extinguished over us. (Letter to Felice) [Wenn ich ihn (den alten, nicht abgeschickten Brief aus der Anfangsphase unserer Beziehung) lese [...] so sehe ich unter unsinnigen weiteren Hoffnungen [...] daß alles so viel schöner geworden ist und daß man glauben möchte, daß der gute Stern, der uns gefuhrt hat, niemals uber uns auslöschen wird. (Briefe an Felice)

Predetermined linguistic elements lie at the base of these two pairs. On the one hand we have a proverb; however, since its origin threatens to disappear from the consciousness of the linguistic community, it has come close to a proverbial comparison in its usage: "I am like a lost sheep that has lost its way" [Ich bin wie ein verirtes und verlorenes Schaf] confesses the prayerful voice of Psalm 119. On the other hand, the following saying is the point of departure: "to be guided by a good star" [von einem guten Stern geleitet werden].

The notion of the star which shows the right path is used each time for the same circumstances, indeed in different types of texts, written at different times. Similarly, this notion can be found in two 
further texts in the letters and diaries in formulations which draw upon each other: here, this notion appears as the image of a literary utopia. ${ }^{84}$ Based on this, one can draw the conclusion that they were not found in the instant in which the novel originated, but lay ready to be summoned in the consciousness of the author and simply had to be brought to life in the right place.

If we grant this, it must seem strange at first sight that the manner in which these expressions are used in the personal writings is in one significant point different from their use in the fictional narrative writings: the passage in the correspondence conveys a stronger image than the passage in the Castle which is contextually related to it. In the latter case Kafka clearly accepts a very clumsy and comparatively inconspicuous formulation in order to avoid the verb "to extinguish" [verlöschen] which imposes itself as a counter-notion to that of the brightly shining star in the nightly firmament.

Even more pronounced is the difference in the case of the other notional complex. The final sentence of the diary develops a semantic extension which Kafka had already undertaken with the proverb: a sheep wiich is running after a lost (and for this reason bleating) creature of the same species has as little cause for this as the writer has energy to deplore his abandonment, which incidentally happens to be "in the night and the mountains" [in der Nacht und im Gebirge] and is thus more precisely localised in contrast to the biblical wording.

The fact that Kafka occasionally uses proverbial sayings in his autobiographical writings with more colourful, independent and finer nuances than in his novels is, to be sure, not to be evaluated as an accident of the literary profession. Rather, it belongs to his aesthetic calculation: the use of metaphorical expressions in fictional contexts brings with itself a problem of a particular kind. The concretization which accompanies the expression is not supposed to lead the reader out of the text, because in this way the desired closure of the epic world would be disrupted. These facts and circumstances which have taken on

84. T 324f, and F 65; cf. Br 190 and 430. 
form in this way are to integrate themselves as seamlessly as possible into the domain predetermined by the context.

This requirement can be fulfilled most easily by ensuring that the components of the respective metaphorical expressions in question reappear in other parts of the work, regardless at what level. In this way the otherwise foreign metaphorical elements or determining expressions in comparisons and metaphors become members of comprehensive referential relationships, integral parts of the narrative which ideally no longer knows any blind motives or functionless building blocks even if of lesser meaning and syntactical power. ${ }^{85}$

How sensitive Kafka was in this respect is made clear by a deletion in the story Josephine, the Singer or the Mouse People [Josephine, die Sängerin oder Das Volk der Mäuse]. He undertook this deletion apparently when he was preparing the manuscript for publication. In this revision he deleted a 'how'-comparison, in which we hear about a rich man whom someone wants to help enjoy his wealth without being interrupted. This idea would have brought social relationships to the reader's attention in an unequivocal and direct manner. This would have contradicted the specification of the mouse as main character which he was working on at the same time, and thus this would have disrupted the hermetic nature which the author desired for his story. ${ }^{86}$

For this reason it is understandable that the frame of mind which is ascribed to many an immigrant in New York could not have been expressed through a feeling of loss which a nightly mountain scene

85. See Hartmut Binder, "Erzlhhlstrategien in Kafkas Verwandlung," Euphorion, 80 (1986), pp. 175-185.

86. Cf. Hartmut Binder, Kafka. Der Schaffensprozeß (Frankfurt/M., 1983), p. 375f. It is true that Kafka brought the mice explicitly into the story only in the edition of the text which appeared in the collection Ein Hungerkïnstler (cf. Max Brod, Über Franz Kafka [Frankfurt/M., 1966], p. 179f.). But one should not conclude from this that Kafka had only developed this idea on his death bed that the singer's species were animals of the above kind. 
brings about. It would have been equally unsuitable to let the star burn on (which at the beginning of the Castle [Schloß] led the innkeeper to Klamm) even if only in the figurative sense. For fog and darkness form the background of an action which is to underline K.'s sad, opaque fate. This is a very traditional and frequently used epic device. The "dreary night" [trübe Nacht] which prevails in the chapter in question is illuminated merely by hand-held lanterns. ${ }^{87}$

But then should not the whole phrase have been suppressed? This expression may well have imposed itsclf on Kafka as the autobiographical background of an undertaking, i. e., writing, that he regarded in particular as a means to ameliorate his psychic suffering. In addition, the breadth of association and the degree of popularity of this expression allowed him to sum up the circumstances surrounding the "star" as vaguely as he wished. Apart from all of this, he was mostly concerned with establishing a parallel between the messenger who had called the innkeeper to Klamm, and the messenger from the castle whom K. encounters as Klamm's emissary. The expression concerning the good star is a frequently used structural device in the novel. ${ }^{88}$ It is employed again in a scene in which Bamabas hands over a message from Klamm to the land surveyor in the darkest night. It formally frames two actions which are supposed to find their reflection in each other.

However, now there was the difficulty of mentioning the stars without showing their radiance, for Barnabas is hardly able to bring the land surveyor closer to his desired goal because he too is unable to lead anyone to Klamm.

The variants to this passage show that Kafka could not immediately express what he wanted to say. $K$. regarded the message which had been delivered to him as a misunderstanding, even the messenger was not able to offer him any help,

87. Franz Kafka, Das Schloß, ed. by Malcolm Pasley (Frankfurt/M., 1982), p. 366; compare pp. 7, 186, and 195 (henceforth: S). (Critical edition.)

88. See particularly Hartmut Binder, Kafka in neuer Sicht, pp. 420-485. 
for he himself was defenceless, only his smile glowed like an incomprehensible star out of an incomprehensible darkness [denn er selbst war wehrlos, nur sein Lächeln leuchtete wie ein unbegreiflicher Stern aus unbegreiflicher Finsternis].

So much for the first attempt. Of course, it could not satisfy because the darkness described in this way insufficiently attenuated the effect of the stars and would not have corresponded with the dark frame which was supposed to enclose the action of the novel.

In order to darken the scene further, in his next attempt Kafka eradicates the comparison which he has just worked out and changes the expression to "like the light of the [...]" [wie der Schein der (...)] lanterns, one might perhaps add. Carried by the approaching helpers and sailing towards the land surveyor like swaying points of light, these lanterns were necessary for the continuation of the narrative. Held high, they later enable $\mathrm{K}$. to read the letter he received. And because it was one of Kafka's principles of representation to use compositional elements as economically as possible, it was only logical to illuminate the night scene with the help of the lanterns which had their role to play in the further develpment of the narration.

But even while he was thinking about this and writing it down, he must have noticed that the now correct illumination of the night scene had led him to sacrifice the link with the parallel passage, which was just as important to him. The stars which had established this link had now completely disappeared. For this reason Kafka now rejects a second time the chosen comparison and replaces it with a less illuminating one, which could serve both of the very different narrative intentions. The messanger's smile continues to shine, but it helps "just as little as the stars above [...]" [ebensowenig wie die Sterne oben (...)]. Later he adds "[...] against the storm down here" [(...) gegen den Sturmwind hier unten], and thus dims the scene even more, in that he again makes reference to the weather that introduced the chapter. ${ }^{89}$

Supposedly in order to avoid such difficulties Kafka prefers to use expressions in his novels whose referential domains are those of

89. S 189 (cf. 186) and Franz Kafka, Das Schloß. Apparatband, p. 292. 
bodily movements, mime and gesture. In these cases we are dealing with factors that recur in a natural fashion in the habitus and in the comportment of characters and thus lead the gaze of the observer much less out of the narrative context.

Sometimes Kafka improves the desired integration of traditional word combinations by the manner in which they are embedded in the context, as in Olga's narration:

When I saw the radiance in [Bamabas'] eyes as I made my reports, I became frightened, and yet I did not stop for something too great seemed to be at stake. [Wenn ich bei meinen Berichten den Glanz in seinen [des Barnabas] Augen sah (...) erschrak ich und ließ doch nicht ab, zu Großes schien mir auf dem Spiel zu sein.]

Apparently here the two sayings "to be in the game" [im Spiel sein] and "to be at stake" [auf dem Spiel stehen] have been contaminated by each other. It cannot be determined here whether Kafka uses a variant that was common in Prague, or whether he wants to alert the reader to take note of the deviation. The reader might remember that Olga had mentioned in the preceding sentence that she had been no more than a "toy" for those servants in the Herrenhof who had brought her the uplifting news from Barnabas, a toy, "which they attempted to break with a vengeance" ["das zu zerbrechen sie sich wütend anstrengten"]. If the reader remembers this, then his associations are not grounded in the action alone, but are linked at the same time with the larger context of the childlike, which is associated with the castle and its inhabitants in ever new gradations. ${ }^{90}$

Comparisons and metaphors that are invented are of course more easily integrated in their singularity than proverbial sayings and expressions whose visualization lies outside of the horizon of the work. In that case the required comparisons and metaphors can, from the beginning, be adapted to the reality of an already existing epic context or one which still needs to be created. Thus, we hear that the pinnacles of the round building in the Castle are said to have been "drawn as if by the fearful or careless hand of a child" ["wie von ängstlicher oder

90. S 355. 
nachlässiger Kinderhand gezeichnet"]. This comparison fits well into the overall contextual framework of the novel, even though it is not taken from the typical linguistic arsenal with whose help the dilapidated walls of a castle are usually described. For there are over fifty places in the novel where incidents are related to the world of the child, quite apart from the fact that students as a collective and the twelve year old Hans as a single person are part of the narration. There are also further comparisons and metaphors which use the qualifying term "youth." If one adds to this that childishness is a characteristic of the officials of the castle and everything they represent, then one can talk about a metaphorical network which consists of similar pictorial components and which is drawn over the whole text. ${ }^{91}$

This method has the disadvantage that the usage of particular phrases, which are dependent on their own specific metaphorical context, creates problems for their epic integration. However, an advantage of a different kind generally makes up for this. The "situational images" presented in the text have clearly defined limits of visualization. These images lend themselves better to integration than do abstract concepts. At the same time they are characterized by greater semantic imprecision than pictures of a different kind. This accounts for the fact that they can be more easily adapted to different contexts. In this fashion the creation of associatively rich textures is possible with little effort and it is likely not only for formal reasons that Kafka considered these suitable. ${ }^{92}$

It is significant in this context that fictive, i. e. invented, expressions are quoted in three different places in the novel. They illustrate characteristics of the castle bureaucracy in all its multiplicity

91. P 18. cf. Barbara Beutner, Die Bildsprache Franz Kafkas (pp. $292-$ 294 and 307-309) for her compilations of images in Kafka's stories and novels.

92. Wolfgang Fleischer, Phraseologie, p. 171f. 
and are supposed to stimulate and hinder the imaginative capabilities of the reader..$^{93}$

A good example of the integration of a proverbial saying with the novel as a whole can be seen in the little dialogue between $K$. and the factory owner in The Trial. Kafka employs the expression "to carry one's cross" without any danger of sacrificing the semantic context whose aim it was to guarantee the narrative independence of the fictional world. For, the realm of theological associations which imposes itself is greatly developed at a later stage in the novel: in the Cathedral chapter $\mathrm{K}$. notices several altars, contemplates an altarpiece which

93. S 273: "There is a saying, maybe you know it: 'Official decisions are shy like young girls." "That's a good observation," said K., taking it even more seriously than Olga, "a good observation, possibly there are other qualities that these decisions have in common with girls." "Perhaps," said Olga, "but I don't really understand what you mean. Perhaps you mean it as a compliment. However, as far as the official clothing is concerned (...)" [Es ist hier eine Redensart, vielleicht kennst Du sie: 'amtliche Entscheidungen sind scheu wie junge Mädchen'." "Das ist eine gute Beobachtung," sagte K., er nahm es noch emster als Olga, "eine gute Beobachtung, die Entscheidungen mögen noch andere Eigenschaften mit Mädchen gemeinsam haben." "Vielleicht," sagte Olga, "ich weiß freilich nicht, wie Du es meinst. Vielleicht meinst Du es gar lobend. Aber was das Amtskleid betrifft (...)].

S 348: "I hope you have it as good as a servant" is an official blessing and indeed, as far as a good life is concerned, the servants are really the masters of the castle." ['es möge Dir gehn wie einem Diener' heißt ein Segensspruch der Beamten und tatsächlich sollen, was Wohlleben betrifft, die Diener die eigentlichen Herren im Schloß sein.]

S 405: "For example, why can't the doors be locked here? There is indeed a reason. Because there is an old saying which says that secretaries' doors are supposed to be open at all times. But that was not to be taken so literally, either." [Warum sind auch die Turen hier unversperrbar, nicht? Das hat freilich seinen Grund. Weil nach einem alten Spruch die Türen der Sekretäre immer offen sein sollen. Aber so wörtlich mußte auch das allerdings nicht genommen werden.] 
depicts the burial of Christ, looks at the golden cross attached to the pulpit, and finally crosses himself before a priest who suddenly appears. ${ }^{94}$ In this fashion the productive appropriation of the associating reader remains attached to the closed world of the novel.

But one could doubt whether Kafka knew his texts by heart to such an extent that he knew in advance which circumstances, objects and expressions would be represented in detail. This is especially true in view of his claim (which no one can deny) that he was dependent on his literary inspiration and thus could not foresee how a project which had been undertaken would develop. ${ }^{95}$ In the case of the present example, such objections do not apply. In 1914 when Kafka formulated the discussion in question between $\mathrm{K}$. and the factory owner, that part of the cathedral chapter in which the cross metaphor is developed was already written. ${ }^{96}$

In addition, the expression which is put into the factory owner's mouth (particularly the formal variant which he choses) ${ }^{97}$ allows us to establish a link to a statement documented in Kafka's letters and diaries, that 'he had a heavy load to carry because of his own personal situation. ${ }^{.98}$ And this metaphor, in turn, is developed in

94. P 280, 281, 284.

95. Cf. Max Brod, Über Franz Kafka, p. 349, where the following statement by Kafka is reported: "One must write into the dark like into a tunnel." [Man muß ins Dunkel hineinschreiben wie in einen Tunnel.] For verification of this statement, see Hartmut Binder, Kafka. Der Schaffensprozeß, passim.

96. Cf. Franz Kafka, Der Prozeß. Apparatband, pp. 113f. and 117.

97. Had he used the common altemative "everyone has a cross to bear," the generalization which Kafka had intended would have already been part of the expression. Cf. Lutz Röhrich, Lexikon der sprichwörtlichen Redensarten, vol. 2, p. 543.

98. Cf. Hartmut Binder, "Kafka und die Skulpturen," Jahrbuch der Deutschen Schillergesellschaft, 16 (1972), pp. 639-641. 
several places in The Trial: the backs of the accused are "bent" [geneigt], their knees are "bent" [geknickt], the sexton in the cathedral "hunches over with a crooked back" [mit krummem Rücken]; the pulpit, which is mentioned in the same context, is described "as if it were meant as a torment for the preacher" [wie zur Qual des Predigers bestimmt]. When the preacher finally climbs up to the pulpit, the low set roof seems to crush him down [niederzudrücken]. ${ }^{99}$ In this way an implicit interaction of motifs is established between the narrative and the metaphorical contexts out of which this expression is created.

Even expressions that are based on everyday experiences are treated in a similar manner. Since The Castle contains for the most part direct speech and dialogue, we continually encounter metaphorizations which originate in phrases. We can ascribe this to the increased need on the part of an author who works primarily with images to make complex constructions (which are largely abstract and rarely show scenic elaboration) more attractive through perceptible details. Whenever possible, though, Kafka avoids presenting such elements individually. Rather, he attempts to make them into key elements associated with particular characters. These elements appear in different places in their dialogues, or are represented in general contexts which appear in connection with many characters.

For instance, the circumstances which confront the land surveyor make him fear that the castle authorities may be forced one day "to get rid of him" [ihn aus dem Weg zu răumen]. The central expression implied here reveals part of its concrete meaning through the words "step by step" [Schritt für Schritt] (mentioned at the beginning of the novel) and similar expressions. It represents the main wish $\mathrm{K}$. has in connection with his stay. Like the officials, he wants to have a clear path. ${ }^{100}$ But again and again the path he is pursuing so relentlessly is in

99. P 93, 285, 283, 290.

100. S 93, 20 and 410, cf. 94: "[...] while before great care had been necessary, a glance to all sides before every step." [(...) während sonst aber immer große Vorsicht nötig war, ein Herumblicken nach allen Seiten vor jedem Schritt.] 
danger of being blocked [verlegt] by adversaries. ${ }^{101}$ In this connection the innkeeper informs him that he is "always in the way" [überall im Weg]. Thus, she has recourse to another expression which is indebted to the same semantic context in order to cite one of the reasons for the animosity he encounters. ${ }^{102}$

101. The expression, "to block someone's way" Ljemandem den Weg verlegen], means to interfere decisively in someone's pursuit of his goals and thereby put him into a hopeless situation.

102. Cf. P 86: "If he stayed at home and led his normal life, then he would be a thousand times superior to any one of these people and be able to remove someone from his path with a good kick." [Wenn er zuhause bliebe und sein gewohntes Leben führen würde, war er jedem dieser Leute tausendfach überlegen und konnte jeden mit einem FuBtritt von seinem Wege räumen.] The mention of the kick as well as the change of the fixed form of the expression enliven the event which lies at the heart of the expression and adapt it in the same way in which Kafka uses the dog metaphor in The Trial: for instance, in the Metamorphosis, Gregor Samsa is driven back into his room by his father's kick and is badly injured (E 93); in addition, in Swabian German the expression "Hundstritt" stands for a kick which expresses furious disregard and usually applies to dogs. (Cf. Hermann Fischer, Schwäbisches Wörterbuch, Bd. 3, Tubingen, 1911, col. 1895). For this reason, the Head Clerk K. probably regards his adversaries in the above scene as inferior beings, dogs. But at the end of the novel $\mathrm{K}$. himself, who had rightly called the other accused, Block, a lawyer's dog [Hund des Advocaten] (P 265) due to his servile, boot-licking behaviour, experiences what he had wanted to do to others since we see him dying like a dog [wie ein Hund] (P 312).

It cannot just be a coincidence that there is a similar expression in a statement by Kafka which unites "way" and "dog." In 1907 Kafka predicts his future to Max Brod: "My path is not very good at all, and I must - that much I can see - die like a dog." [Mein Weg ist gar nicht gut und ich muß - soviel Ubersicht habe ich - wie ein Hund zugrunde gehen.] (Max Brod, Über Franz Kafka, p. 67). In The Trial, as in America (Der Verschollene), Kafka uses the dog metaphor as a representation of disdain, inferiority and humiliating selfabandonment. In The Castle Kafka uses it exclusively to illustrate animalistic lust which is normally attributed to the dog because it 
Besides, the original meaning of the events upon which the last mentioned metaphorical expressions rely are developed on the narrative level of the novel itself: on the one hand, Fuhrmann Gerstäcker literally gets the land surveyor off the road to the castle. Thus, the expression "to get someone out of the way" [jemanden aus dcm Weg räumen] is carried out in its original sense. On the other hand, while the land surveyor is waiting for Klamm at the inn, he is told by the village secretary "to get himself out of the way" [sich selbst zu vertreiben] in order to free the way for the office executive who wanted to return to the castle without being bothered. ${ }^{103}$

It may even be that the expression as such does not appear and that it is realized exclusively in the form of narrated action. If one takes as a starting point that the expression "to put a foot on the neck or chest" [einem den Fuß auf den Nacken oder die Brust setzen] is for Kafka a picture of complete subjugation or final capitulation, then one can see episodes in America, The Castle and in a fragment which is related to hunting metaphors. These metaphorizations take literally the action which is implicit in the formulation, particularly since the action

copulates on the street. Cf. S 75 (during their embraces, Frieda and $K$. desperately paw the ground like dogs [wie Hunde verzweifelt am Boden] and lick each others' face [breit uber des andern Gesicht]); $\mathbf{S}$ 250 (K. as a clever predator [schlaues Raubtier] who has pulled Frieda to himself and, in another variant which Kafka eliminated, ripped open her clothing "with hands and teeth" [mit Händen und Zähnen] (Franz Kafka, Das Schloß. Apparatband, p. 185)); S 345 (where there is mention of the "dog-like lusting fellows" [hindisch lusternen Gesellen]) and S 392 (where a helper "lurks around Frieda like a hungry dog" [wie ein hungriger Hund Frieda umlauert]).

103. S 168, cf. 28: "The whole scene did not create an impression of particular friendliness, but rather of a very selfish, fearful and almost pedantic striving to get $\mathrm{K}$. away from in front of the house." [Das Ganze machte nicht den Eindruck besonderer Freundlichkeit, sondern eher den einer Art sehr eigensüchtigen ängstlichen fast pedantischen Bestrebens, K. von seinem Platz vor dem Hause wegzuschaffen.] 
appears to be carried out in a regular, meaningful fashion which corresponds to the expression. ${ }^{104}$

A further example: in one place in The Castle the barmaid Frieda reproaches her friend $K$. that the innkeeper had finally "found out about him" [(ihm auf die) Schliche gekommen] ${ }^{105}$ and thus knew his innermost wishes and intentions. One must presuppose that Kafka, as has been repeatedly documented, had a particular imaginative bent which made him visualize immediately the concept lying behind the expression. Thus, he saw before him the hunter, surreptitiously following his game: this is most probably why the land surveyor is likened to a man who pursues his own affairs "like a hunting dog" [wie ein Jagdhund], who leaves Barnabas' house by secret paths, and who "circles around the courtyard ...like the fox circles around the chicken coop."106

Moreover, the last mentioned metaphorical construct is taken up in another place and further developed, and thereby related to the whole of the novel: the noise of the secretaries, waiting for their files early in the morning, resounds in the ears of the land surveyor who is hanging about in the hall: "like the break of day in the chicken coop, like the joy of being in complete harmony with the waking day, somewhere a man even imitated the call of a rooster" [wie der Aufbruch im Hühnerstall, wie die Freude, in völliger Übereinstimmung mit dem

104. A 295; S 67 and $\mathrm{H} 160$.

105. S 243. Kafka uses the following variant: "auf Deine Schliche gekommen."

106. Franz Kafka, Das Schloß. Apparatband, pp. 412 and 422 as well as 430; cf. p. 389, H 182 and Karl-Heinz Fingerhut, Die Funktion der Tierfiguren in Werke Franz Kafkas, p. 209. The possible objection that Kafka's deletions continually obviated the contextualizations which I have indicated can be countered by the observation that he frequently used the deleted passages later and thus changed the content only in terms of sequence. One can therefore assume that in the completed novel all types of imagery would have been linked to the whole by means of parallels. 
erwachenden Tag zu sein, irgendwo ahmte sogar ein Herr den Ruf eines Hahnes nach]. ${ }^{107}$

But this does not exhaust the linking of the metaphorical elements with other passages: not only $\mathrm{K}$. but also Barnabas prowls through the halls. Then there are the officials who seem to be lying in wait for the maids employed there. And finally there is Pepi who in the same manner is on the lookout for Klamm. ${ }^{108}$ Other passages unfold further aspects of this type of hunt for human victims: when Pepi wants to "get onto the trail" [auf die Spur] of her enemy Frieda, ${ }^{109}$ then what she really wants is to discover her game's trail and to hunt it in the literal sense of the expression. In this again, she resembles the officials who, as Olga reports, when hiring persons of ill repute, "almost against their own will, love the smell of such game" [förmlich gegen ihren Willen den Geruch solchen Wildes lieben] and then take the appropriate measures. ${ }^{110}$

Finally, those phrases are important which relate to eye imagery in The Castle. He would not let K. "out of his sight" [aus den Augen verlieren], writes Klamm in his first official message and characteristically concludes his second letter to the land surveryor with the statement, "I will keep an eye on you" [Ich behalte Sie im Auge]. This expression has the same meaning and is also based on a saying. As a contrast, we are dealing with an antithetical combination of common expressions when the innkeeper wants to "open Frieda's eyes" [die Augen offnen], whereas Barnabas' family is said to be "struck with blindness" [mit Blindheit geschlagen] on the day of the Fire Department celebration. This formulation, by the way, was too unclear for Kafka and he replaced it in the following sentence with "through the fog" [durch allen Nebel], even though this type of weather had never been

107. S 430 .

108. S 274, 458 and 473 .

109. S 460 .

110. S 352. 
mentioned before and is also a little unlikely considering that this occasion is taking place in mid-summer. ${ }^{11}$

The same metaphorical context can be seen in several other passages. Thus, $\mathrm{K}$. is "groping" [tappte] for Klamm. This verb requires the completion "in the dark" [im Dunkeln] and thereby suggests weak sight. Another example is found when the land surveyor says of himself, again using a saying, that he "was not blind" [nicht blind] to Amalia's merits, or when he uses an analogy to characterize Bamabas' as yet unsuccessful work: "You can encourage somcone whose eyes are bound only so much to look through the cloth, he will never see; only when you take off the cloth will he be able to see" [Du kannst jemanden, der die Augen verbunden hat noch so sehr aufmuntern, durch das Tuch zu starren, er wird doch niemals sehn; erst wenn man ihm das Tuch abnimmt, kann er sehn]. ${ }^{112}$

These examples show that Kafka is very inventive in his efforts to integrate sayings in an aesthetically pleasing manner. The links are found on many different levels: they reach from clear formal parallels and sayings that have the same sense, to metaphors as carriers of similar images. They reach up to personifications of real characters, to narrative distributions, and finally there are analogies that try to clarify the elements of a particular case by drawing on comparable examples from everyday life. ${ }^{113}$

111. S 40, 187, Franz Kafka, Das Schloß. Apparatband, p. 306 (cf. p. 385) and 311 .

112. Franz Kafka, Das Schloß. Apparatband, pp. 203, 371 and 291.

113. It makes sense that Kafka's particular use of sayings constitutes a problem for translation. Werner Koller formulates it as follows: "In cases where sayings are used playfully with their (relative) syntactical and lexical solidity, where one experiments with their fundamental imagistic or literal meaning, where imagistic associations are intended, where individual elements within expressions are implicitly or explicitly integrated in the co(n)text, then the translation reaches its limits and most translation procedures cannot be used." (Redensarten, p. 199). The translations that Koller has examined in 
America illustrates how Kafka underlines the social position of individual speakers through his use of proverbial comparisons. In The Castle, moreover, the principle of labelling characters in phrases is fully developed into a system which informs the work as a whole. Clearly, Kafka intended to contrast the different social origins of characters by means of linguistic expression and to create stylistic variance. In this enterprise a prime means of characterization is the type of reasoning as well as the more or less evident ability to understand and interpret events, and linguistic expression.

Secretary Bürgel belongs to a group of castle officials who are all "very educated" [sehr gebildet] and in their "specialty (...are able) to grasp whole streams of thought in one word" [auf ein Wort hin gleich ganze Gedankenreihen durchschauen]. ${ }^{114}$ His nightly torrent of words spoken during an audience which is not or only half given in an official function, reveals evidence of only very few linguistically solidified discursive elements: a sort of proverbial comparison which however does not function as a stereotype because of its syntactical structure and specific referential level, ${ }^{\mathrm{H}}{ }^{\mathrm{a}}$ a somewhat flat expression in connection with a strong imagistic verb, ${ }^{116}$ a functional verbal structure, ${ }^{117}$ as well

this respect have led him to the conclusion that they were clearer and more precise and deviated less from the norms of language usage than the original, and were therefore easier to read (p. 205).

114. S 340.

115. S 421: "the party demands sacrificies of us in the middle of the night like a robber in the forest" [die Partei zwingt uns in der Nacht wie der Räuber im Wald Opfer ab].

116. S 418: "Many a man has already lost the game, because, believing that he could not get on through legitimate openings, tried to slip through illegitimate ones." [Mancher hat schon die Partie verloren, weil er, da er an zuständiger Stelle nicht vorwärtszukommen glaubte, an unzuständiger durchzuschlïpfen versuchte.] 
as a metaphor which depicts the castle organism as a superbly fine sieve. Only a party that existed as a "peculiar and very distinctly formed, small and versatile kernel" [sonderbar und ganz bestimmt geformtes, kleines und geschicktes Körnchen] would be able "to glide through [durchzugleiten]." 118 Not really very much on eighteen pages that contain, by way of contrast, organized abstract explanations of official matters.

On the other hand, the nighttime visitor, $\mathrm{K}$., is clearly more metaphorical, even though his passages make up only a small fraction of the chapter: dream images, ${ }^{119}$ "as if" sentences, partially reinforced through sayings which explain Bürgel's abstract elaborations of key terms such as "way" [Weg] and "wandering" [Wanderung], ${ }^{120}$ an adverbial phrase, ${ }^{121}$ and finally a proverb ${ }^{122}$ which has been transformed

117. S 424: "If you hesitate even longer, Erlanger is going to overwhelm me." [Wenn Sie noch lange zögern, kommt Erlanger über mich]. Functional verbal structures are syntactically solid relations in which the meanings of the individual parts are not entirely dissolved but work together in such a manner to produce a semantic modification that is equal to the result of a type of action. (Wolfgang Fleischer, Phraseologie, p. 139f)

118. S 421 .

119. S $415 f$.

120. S 410,413 and 419.

121. S 409 "effortlessly" [aus dem Handgelenk]: fully idiomatic and functions as a metaphor.

122. S 419: "Rattle on, old mill, rattle on," he thought. "You're rattling only for me." [Klappere Mühle klappere, dachte er. Du klapperst nur für mich.] Cf. Horst and Annelies Beyer, Sprichwörterlexikon. Sprichwörter und sprichwörtliche Ausdrücke aus deutschen Sammlungen vom 16. Jahrhundert bis zur Gegenwart, 4th edition (Leipzig, 1988), p. 312: "You have to let the mill rattle" [Man muß die Mühle klappern lassen]. 
into the form of a communicative commentary ${ }^{123}$ further enliven this obdurate theme.

Olga, the "peasant girl" from the village, ${ }^{124}$ is significantly differentiated from the castle secretary by linguistic means. In her dialogues, which stretch over about ninety pages and constitute quantitatively the most extensive single enunciation, Kafka uses sayings to a much greater extent. There are proverbial sayings ${ }^{125}$ and expressions ${ }^{126}$ which, greatly changed in their wording, are either supposed to reflect Prague colloquial speech or Olga's ability to adapt prefabricated linguistic material to the circumstances in question. ${ }^{127}$ One can add to this the image of someone who is dying of thirst which has a stronger impact than an expression taken from the realm of 'drinking' used by the socially superior Bürgel. ${ }^{128}$ These expressions form a string of motifs which go beyond the melaphorical level. The

123. For an explanation of this term, cf. Wolfgang Fleischer, Phraseologie, p. 135.

124. S 314.

125. S 311 "to be struck with blindness" [mit Blindheit geschlagen sein].

126. S 334 "to rub one's hands together" [sich die Hände reiben].

127. S 335: ("not to raise a finger" [keinen Finger rühren], here as an occasional variant "to raise a finger against someone" [einen Finger gegen jemanden r(thren]); 353 ("to be underway" instead of "to be in the hall" [im Gang sein], referring not to a situation but to people); and 355 ("to be at stake" [auf dem Spiel sein]).

128. Olga: "and he, who (...) had nearly died thirsting for these things, so great was his desire due to the circumstances of our family, he drank everything up" [und er, der (...) infolge der Lage unserer Familie fast verdurstete vor Verlangen nach diesen Dingen, er trank alles in sich hinein], S 353. Burgel: "The party that is sitting there, always expected, expected with real thirst, and in a very sensible way is always seen as unreachable." [Die niemals gesehene, immer erwartete, mit wahrem Durst erwartete und immer vernünftiger Weise als unerreichbar angesehene Partei sitzt da.] S 422. 
same is true of those scenes which take place in the bar of the two inns and other places in which the land surveyor is enjoying rum, cognac or beer. ${ }^{129}$

Finally, Olga's elaborations gain form through metaphors which hint at proverbial comparisons without making them explicit, ${ }^{130}$ through creatively integrated parallel constructions, ${ }^{131}$ and through predetermined linguistic material of a different kind, of which I shall give one example: in order to illustrate the noise coming from the Fire Department celebration, Olga says: "Hearing that, it seemed as if the Turks had come" [wenn man das horte, glaubte man, die Türken seien schon da]. ${ }^{132}$ Evidently we are dealing with a metaphor here that originates in historical events ${ }^{133}$ and entered common usage in Austria in the form of a partial sentence which has been transformed into a saying. ${ }^{134}$

The extent and form of Olga's sayings give an impression of well-formed speech. Since the speaker is less educated than Bürgel, the characteristic style of her speech has a larger component of everyday speech. However, due to her middle class origin, she uses these expressions carefully and thoughtfully.

129. Cf, for instance $S 13,33,74,164 f$. and 171 .

130. S 318: "Barnabas, then young as a spring lamb (...)" [Bamabas, damals jung wie ein Lammchen (...)]. The common expression would be "gentle as a lamb" [sanft wie ein Lummchen].

131. S 331: "She stood there eye to eye with the truth" Aug in Aug mit der Wahrheit stand sie].

132. S 299.

133. Cf. Jacob and Wilhelm Grimm, Deutsches Wörterbuch, vol. 22 (Müchen, 1984); col. 1851-1853.

134. For this notion, see Wolfgang Fleischer, Phraseologie, p. 107f. 
Again, we see another picture when we examine the third and last long discursive construction in The Castle which is spoken by Pepi. This maid is not only quite young and so ignorant ${ }^{135}$ that the monstrous products of her unrestrained fantasy become mere prattle, ${ }^{136}$ but she also belongs to the lowest levels of the society portrayed in The Castle. Kafka expresses this circumstance by enriching her remarks, which make up only a third of Olga's, with fixed lexical combinations which are not to be found elsewhere in his works. ${ }^{137}$ The breadth of the fixed expressions that we encounter here stretches from communicative formulas, ${ }^{138}$ word pairs, ${ }^{139}$ clichés, ${ }^{140}$ nominative expressions, ${ }^{141}$ and partially idiomatic functional verb constructions $^{142}$ to unrefined, exaggerated comparisons which resemble

135. S 159 and 174.

136. S 315 and 479.

137. We also encounter this technique in partial form in Franz Werfel's novel, Graduation Day [Der Abituriententag], cf. p. 110, where a simple woman speaks: "Professor Kio says that you've really gone back and that you will come to a bad end." [Professor Kio sagt, daß du ganz erschreckend zurickgegangen bist und $\mathrm{daB}$ es mit dir ein schlimmes Ende nehmen wird.] This is a Prague German expression meaning that the scholastic achievements of the individual have deteriorated terribly. See also notes 47 and 144 of this article.

138. S 463 ("in the name of the devil" [in Teufels Namen] and 465 "Good Heavens!" [Du lieber Himme!!]

139. S 456 ("lost and forgotten" [verloren und vergessen]) and 474 ("here and there" [hier und dort]).

140. S 465 ("It is a pity to see his situation." Es ist ein Jammer, seine Lage anzusehen.])

141. S 456 ("that dirty rabble" [dieses schmutzige Pack]).

142. Cf. S 467 ("Your two colleagues remained true to her" [Ihre zwei Kollegen hielten treu zu ihr]) and 458 ("In any case the girls inside are dying from fear" [Jedenfalls vergehn die Mädchen drinnen vor 
fixed expressions ${ }^{143}$ as well as to proverbs ${ }^{144}$ and expressions which have either become clichés due to excessive us ${ }^{145}$ or, in written language, are used only in specific situations. ${ }^{146}$

But it was not only through the accumulation of such prefabricated linguistic building blocks that Kafka wanted to characterize the clichéd thinking of a girl from the lower classes. What is also important is the humble stylistic level of her colloquial remarks which is underlined by the corresponding verbal metaphors, ${ }^{147}$

Angst]).

143. S 455 ("to burn up like a piece of paper in the oven" [verbrennen wie ein Papier im Ofen]) and 456 ("like a job in a mine" [eine Arbeit wie in einem Bergwerk]).

144. S 464 ("there are limits to everything" [alles hat Grenzen]), colloquial in Southern German speaking regions, cf. Lutz Mackensen, Zitate, Redensarten, Sprichwörter, 2nd expanded edition (Wiesbaden, 1981), p. 192; and Franz Werfel, Graduation Day [Der Abituriententag], p. 111: "I've always thought: a young person...But there are limits to that..." [Ich denke mir immer: ein junger Mensch... Aber das hat doch seine Grenzen..."].

145. S 455 ("Even earlier Pepi had not lived from day to day" [Pepi hatte auch fruher nicht in den Tag hinein gelebt]); 460 "to throw one's hands up in pity" [schlägt man vor Mitleid die Hände (uber dem Kopf) zusammen]: probably a colloquial omission of a component as in the already quoted diary entry by Paul Kornfeld; and 478 "to clench one's teeth [die Zähne zusammenbeißen]).

146. S 466 ("and with all these demands he tumbled into the worst trap on the very first evening" [und mit allen diesen Anspruchen plumpst er gleich am ersten Abend in die grobste Falle] instead of "to go into a trap" [in die Falle gehen] in the sense of "to be tricked").

147. S 475 ("to reel off" [hinaufhaspeln]) and 477 ("to run away" [durchbrennen]). 
paratactically arranged redundancies and repetitions, the aim of which is to imitate the language of the lower classes. ${ }^{148}$

As far as the content is concerned, there is not even an attempt at generalization, which still characterizes Olga's speech to a considerable degree. As do uneducated people, Pepi always personalizes her problems and distinguishes herself through directness in erotic affairs, something which Kafka had observed two years previous to this in the case of a chamber maid. ${ }^{149}$

What points in the same direction is that a phrase which Olga uses correctly is used by Pepi as an Austrian colloquial variant. ${ }^{150}$ That different linguistic levels are to be distinguished in this manner is confirmed in other passages which take up again one of the central ideas of the novel: when Pepi talks about the "way up" [Weg nach oben] which $\mathrm{K}$. has opened up for her, Olga believes that every family member's life had taken "a completely new course" [einen ganz neuen Weg] ever since the arrival of the land surveyor in the village. On the other hand, Bürgel declares that parties who appear in the middle of the night always gain things they are not completely entitled to, "which cannot be rectified in the usual expedient fashion, at least not according to our laws" [welche wenigstens nach unseren Vorschriften im gewöhnlichen kurzen Wege nicht mehr gutzumachen sind]. ${ }^{151}$

148. For example, S 455f.: "Pepi (...) knew what this job was all about, she hadn't taken it on without being prepared. One can't take it on unprepared (...)." [Pepi (...) wußte, was es mit dieser Stelle auf sich hatte, unvorbereitet hatte sie die Stelle nicht ubernommen. Unvorbereitet kann man sie gar nicht ubemehmen (...).]

149. Franz Kafka, Briefe an Milena, p. 199.

150. Cf. $S$ 363: ("and wherever one stops is dictated only by fate" [und wo man dabei gerade Halt macht, ist nur durch den Zufall bestimmt]) with 478 ("this is where we're stopping now" [Dabei halten wir jetzt abend]).

151. S 453, 397 and 413. 
While the representative of the lower classes uses a nominative expression, the middle class girl modifies and renders concrete the fixed expression "to take another direction" [eine andere Richtung nehmen"]. Bürgel, on the other hand, uses the term "way" in an entirely nonidiomatic fashion as a free metaphor for the business affairs conducted by the castle authorities.

In this respect it is significant that Pepi's language does not possess any proverbial variants. On the contrary, Kafka makes explicit the chambermaid's habit of repeating fixed phrases: within her discourse expressions ${ }^{152}$ frequently recur directly or at least in idiomatic forms which arise from the same field of images. ${ }^{153}$ But as if he thought that he had done too good a thing here by pushing realist representation too far at the cost of stylistic skill, at least he grants this thoroughly sympathetic character the ability, from time to time, to develop proverbial comparisons ${ }^{154}$ and idiomatic nominal phrases. ${ }^{155}$

152. S 464: ("what was difficult was to find the right man to play the clever game with" [schwer war es nur, einen geeigneten Mann zu finden, mit dem das kluge Spiel zu spielen war]) and 467 ("Pepi could not be tricked by this game" [dieses Spiel konnte Pepi nicht täuschen]).

153. Cf. S 464: ("he would most likely have looked at her with big eyes" [er hätte sie wahrscheinlich mit großen Augen angesehen], i.e. with astonishment) with 469 ("so that one was almost overwhelmed by all the yellow" [so daß einem vor lauter Gelb die Augen ubergingen]. i.e., one almost had to cry at the sight of so much tastelessness).

154. Cf. S 453 ("she sat there at the bar like a spider in a web; only she knew the threads that she had spun everywhere" [sie saß dort im Ausschank wie die Spinne im Netz, hatte überall ihre Fäden, die nur sie kannte]) with 474 ("But this spider has connections which no one knows about" [Aber sie hat, diese Spinne, Verbindungen, von denen niemand weiB]).

155. Cf. S 456 (where it is a question of embittered chambermaids) with 486: ("one has to sweeten one's bitter life, since it is made bitter for us already in our youth so our tongue won't be spoiled" [man muß sich das bittere Leben versußen, es wird uns ja schon in der Jugend 


\section{The Stories}

The phrases that occur in the stories are significant in a different way. Thus, we hear in A Report to an Academy:

Through considerable effort, previously unknown on this earth, I have acquired the average education of a European. That in itself is not very much, but it is significant in that it helped me get out of the cage and in that it enabled me to find this particular escape, this human escape. There is an excellent German saying: to slip away. That is what I did, I slipped away. I had no other way, always knowing that I could not choose freedom. [Durch eine Anstrengung, die sich bisher auf der Erde nicht wiederholt hat, habe ich die Durchschnittsbildung eines Europäers erreicht. Das wäre an sich nicht viel, ist aber insofern doch etwas, als es mir aus dem Käfig half und mir diesen besonderen Ausweg, diesen Menschenausweg verschaffte. Es gibt eine ausgezeichnete deutsche Redensart: sich in die Busche schlagen; das habe ich getan, ich habe mich in die Busche geschlagen. Ich hatte keinen anderen Weg, immer vorausgesetzt, da $B$ nicht die Freiheit zu wählen war. $]^{156}$

First of all, one notices that Kafka does not make use of the common expression "not to have any other choice" [keine andere Wahl haben]. Rather, in order to be more concrete and not to leave the field of images that he has in view, he transforms it into the curious construction "not to have any other way" [keinen anderen Weg haben]. Above all, however, from a philological point of view, he is somewhat inexact when he speaks of a saying here: it is much rather a case of a familiar quotation [Gefluigeltes Wort]. Thus, it is a widely used utterance, expression, or name whose true originator or literary origin is known, in short, it is a quotation which the user identifies as the intellectual property of another. In this case the origin is Gottfried

bitter gemacht, damit sich die Zunge nicht verwöhnt]).

156. E 195. 
Seume's poem "The Savage" [Der Wilde], which was published for the first time in 1793 in Schiller's Neue Thalia. ${ }^{157}$

To be sure, the expression has de facto taken on the character of a proverbial saying for its origin is generally no longer known. The verse: "And he slipped sideways into the bushes" [Und er schlug sich seitwärts in die Büsche"] lives on in the form "to slip (sideways) into the bushes" [sich (seitwärts) in die Büsche schlagen]. ${ }^{158}$ Possibly, Kafka still knew the origin of the phrase: for this reason he may have integrated it into the narration. It really cannot be an accident that the superiority of the savage over European civilization, as depicted in Seume, is also thematized in A Report to an Academy in a similarly ironic fashion.

In a sense one could even claim that since Kafka shared the sentiment he was led to appropriate an image which did not quite fit into the overall context. In fact, Rotpeter mentions in the introduction that he had been captured by a hunting expedition from the Hagenbeck firm which had been lying in wait "in the bushes along the bank" [im Ufergebüsch]. ${ }^{159}$ This is a type of motif-based link between the metaphorization of the expression and the context of the narration.

Yet, the narrator's singularly forceful act can hardly be interpreted as a 'slipping into the bushes.' Rather, the reader cannot but think that someone has the intention of abandoning all efforts leading along a predetermined cultural path of integration and higher development in favour of a natural existence which is free of the rod of intentional, disciplinary acts. But in Kafka's texts such attempts at

157. Georg Büchmann, Geflügelte Worte. Der Zitatenschatz des deutschen Volkes, 35. edition, edited by Winfried Hofmann (Frankfurt/M., Berlin, 1986), p. 137; cf. VIII (Definition) and Lutz Robrich, "Introduction," p. 15: "The correct quotation is a literal one. If it enters popular usage, it often loses its exact meaning."

158. The shorter version changes neither meaning nor formal stylistic marker. Cf. Wolfgang Fleischer, Phraseologie, p. 209.

159. E 185. 
escape are out of the question. The artistic gymnastics in the Variéte which consume all his strength are preferred to escape or life in the zoo.

It is possible, though, that the author wanted to impose such thoughts on his readers. In this case, he would have wanted to satirize his hero (the story is highly comical anyway) in that he makes him use an unsuitable expression, thereby indirectly commenting on the 'real' quality of his average education.

Likewise in The Judgement there is a saying, again a remark made by a character: "I've got your customers here in my pocket" [deine Kundschaft habe ich hier in der Tasche], says old Bendemann (who, in the course of the narration, turns into a "bogeyman" [Schreckbild]), addressing his son and adversary. What he is trying to say is that he can use his son's clientel as he sees fit because he is "still the stronger one" [noch immer der viel Starkere]. ${ }^{160}$ The effect on the person in question is described in the following manner: "'He's got pockets even in his shirts!', Georg said to himself and he believed that he could make him look ridiculous all over the world with this remark. But he thought that only for a moment, because he kept forgetting everything immediately." ["Sogar im Hemd hat er Taschen!" sagte sich Georg und glaubte, er könne ihn mit dieser Bemerkung in der ganzen Welt unmoglich machen. Nur einen Augenblick dachte er das, denn immerfort vergaß er alles]. ${ }^{161}$

One can see clearly at this point Kafka's intentions which inform the narrative structure. On a first level the meaning is not important: rather, what is important is that predetermined language is used at all. Kafka has modelled old Bendemann, who also uses words of a different kind, ${ }^{162}$ on the linguistic patterns of his own father, ${ }^{163}$

160. E 65 .

161. E 66.

162. Cf. E 60: ("now that we've gotten to this issue" [weil wir gerade bei dieser Sache halten"]), 63 ("my dear son" [mein Herr Sohn]), 65 ("old through and through" [alt bis in die Knochen]), and 67 ("no good at all anymore" [gelb zum Wegwerfen]). 
which were characterized by particular expressions and sayings. ${ }^{164}$ In this manner, Kafka wants to illustrate the imaginary world of a 'petit bourgeois' who uses fixed idiomatic expressions excessively and thereby indicates his dependence on prefabricated clichés. Schiller does the same in the first scene in Kabale und Liebe.

In contrast to this the effect of the above mentioned expression by his father is supposed to show that Georg has become incapable of properly guarding himself against these attacks because his feelings overwhelm him. Fear has engulfed him to such an extent that he is becoming irrational and incapable of judging between the truth and importance of his thoughts. And when he associatively links his reflections to the term 'pocket' [Tasche], the difference between the literal and the metaphorical meaning escapes him, which is presupposed

163. See Jürgen Demmer, Franz Kafka, der Dichter der Selbstreflexion. Ein Neuansatz zum Verstehen der Dichtung Kafkas. Dargestellt an der Erzählung "Das Urteil" (München, 1973), p. 187f.

164. Cf. H 170: ("One had only to be happy about something or other, to be filled with the thought of it, to come home and speak of it, and the answer was an ironic sigh, a shaking of the head, a thumping of the fingers on the table: 'Is that all you're worked up about?' or 'What do I care about your problems?' or 'I don't take things so calmly?' or 'What's that going to get you?' or 'What a fuss about nothing!'") [Man mußte nur tiber irgendeine Sache glucklich sein, von ihr erfullt sein, nach Hause kommen und es aussprechen und die Antwort war ein ironisches Seufzen, ein Kopfschuitteln, ein Fingerklopfen auf den Tisch: 'Hab auch schon etwas Schöneres gesehn' oder 'Mir gesagt Deine Sorgen ' oder 'ich hab keinen so geruhten Kopf' oder 'Kauf Dir was dafur!' oder "Auch ein Ereignis!'); p. 172: ("eat first, then speak" [zuerst iß, dann sprich]; T 223 ("Whoever lies down with dogs gets up with roaches" [Wer sich mit Hunden zu Bett legt steht mit Wanzen auf], cf. $\mathrm{H} \mathrm{171);} \mathrm{p.} \mathrm{324:} \mathrm{("Is} \mathrm{there} \mathrm{anyone} \mathrm{who} \mathrm{can}$ understand that today. What do the children know! No one has suffered like that! There's not a child who understands that todayl" [Wer weiß das heute! Was wissen die Kinder! Das hat niemand gelitten! Versteht das heute ein Kind!]); and p. 710 ("You got me into that" [Du hast mich hineingetanzt]), cf. an expression of the mother, p. 558 ("Test it out before you tie yourself down" [Drum prufe, wer sich ewig bindet]). 
in the expression "to stick someone in your pocket" [jemanden in seine Tasche stecken]. This type of behaviour is known in psychology as a lowering of the level of consciousness, the aim of which is to counter excessive strain that cannot be dealt with on the rational level. ${ }^{165}$

The passage in question in The Judgement fits into a referential relationship which begins at an earlier place in the text and which continues until the end. Its aim is to show how Georg increasingly loses his overview and control of the situation until he finally undertakes his externally decreed suicide, lacking all will and as if in a trance. The reader is thereby supposed to understand the necessity of the suicide, even though neither reason nor convincing ethical arguments can be called upon. ${ }^{166}$

Coming from this perspective one should pay attention to the manner in which Kafka links discourse and counter-discourse in The Judgement. One can see that the father repeatedly responds to his son's

165. Cf. for the psychological background of this behaviour: C. G. Jung, "Die psychopathologische Bedeutung des Assoziationsexperimentes" in C. G. Jung, Experimentelle Untersuchungen (Olten and Freiburg im B., 1979), pp. 425 and $434 f$. The lack of concentration or strong emotions which reduce the ability to concentrate (Georg is "confused" [zerstreut], E 64) lead, for example, in Jung's diagnostic experiments on association to the following result: the experimental subjects react more intensely to stimulant words by means of expressions which can clearly be related to these words and which sound like them. This means that meaningful relationships between stimulation and reaction are mechanically replaced by superficial links. The "abaissement du niveau mental" (the term comes from Pierre Janet) is fundamenal to such linguistic behaviour and is continually accompanied by motor excitement. In this particular case it expresses itself through purposeless body movements (Georg wants to approach his father, then half way there tums around, and distances himself as much as possible, E 64) as well as in uncontrolled expressive movements (Georg bites his tongue and grimaces, E 65f.).

166. We are dealing here with a structural principle which is frequently used by Kafka. Cf. Hartmut Binder, Erzählstrategien in Kafkas 'Verwandlung,' pp. 185-195. 
remarks with terms which the son has just introduced into the discussion, and vice versa. ${ }^{16}$ This cannot be an accident. It is supposed to show that there is no true exchange of ideas here where the partners understand each other on the level of content by picking up on and developing each other's statements. Rather, what we have here is a superficial and mechanical repetition of what was said whereby each speaker is preoccupied with other matters in his thoughts.

How Kafka himself wanted such mimicking of the other's discourse to be regarded is revealed in his diary. In May 1922 he asks himself the following question: "Is that supposed to be a dialogue if one person is silent and the other attempts to substitute for him in order to keep the appearance of a dialogue, i.e. by mimicking, by parodying and thus by parodying oneself." [Heißt es ein Gespräch führen, wenn der andere schweigt und man um den Schein des Gespräches aufrechtzuerhalten, ihn zu ersetzen sucht, also nachahmt, also parodiert, also sich selbst parodiert]. ${ }^{168}$

It is also clear that here the writer is critically illuminating his own linguistic behaviour since Kafka thought he was unable to undertake a coherent, developed dialogue with anyone. In addition, if one considers that elsewhere he accuses himself of having failed in a conversation because he had restricted himself to "trotting out the most elementary remarks" [Abrollen einfaltigster Bemerkungen], then one can risk the assumption that Georg's linguistic behaviour reflects Kafka's

167. These are the pairs:

dunkel - dunkel

nach Petersburg - nach Petersburg

Meinem Freunde - Deinem Freunde (E 59)

anders uberlegt - wieder uberlegt (E 59f.)

diesen Freund - meine Freunde (E 60)

zugedeckt - zugedeckt (E 60)

Komödiant - Komödie gespielt (E 65)

Tasche - Taschen

tausendmal besser - Zehntausendmal (E 66)

168. T 919. 
own insufficiencies which troubled him in fierce battles with his own father. ${ }^{169}$

Finally, however, this is not the only way in which Bendemann's idiomatic expression is connected to the context, as understood by Georg. For when he places the freshly written letter into his pocket on the way to his father, and pulls it out a little at the beginning of the ensuing discusssion only to let it slip in again, ${ }^{170}$ then he acts out symbolically the meaning of the expression "to stick someone in your pocket" [jemanden in die Tasche stecken]. This symbolic act not only repeats in the form of a gesture the remark that he had just announced his impending engagement in the letter to his friend in Petersburg, but at the same time shows that he is the superior party in this correspondence. Georg reassures himself through this game that he in fact has the receiver of the letter "in his pocket" [in der Tasche], in his power, something which had been the object of his earlier reflections.

There is further proof from the stories. In a small fragment the first person narrator reports how the "push and shove" [Gedränge] of his clansmen continually surges back and forth and in this way, so to speak, supports the individual, a confusion which leaves no room for the death wish: "This is what we call hereabouts "to hold someone by the arm," such help is always available here; what one fears like hell is someone who might just fall over and lie there. It's because this sets an example, it's because of the stink of truth that would rise up from him" [Das nennt man hierzulande "einem unter den Arm greifen," solche Hilfe ist hier immer bereit; einen, der ohne Grund umsinken könnte und liegenbliebe, fürchtet man wie den Teufel, es ist wegen des Beispiels, es ist wegen des Gestankes der Wahrheit, der aus ihm steigen witrde. $]^{171}$

169. T 634, cf. F 401, 452 and 454.

170. E 58 and 59.

171. H 249 . 
That Kafka would have intentionally used the singular instead of the commonly accepted plural form cannot be supported, because numerous supporting arms would surely have been more suitable in this context. Either he was unsure about the traditional form, or he was used to this particular form in his native city. What could speak for the first presupposition is that he does not use the expression in its generally accepted meaning. For in this fragment the person who needs help is not supported with money or advice, rather he is supported as he falls. It seems therefore as if Kafka had intended to use the original meaning of the expression as the seed of an epic creation, even though he soon abandoned it. ${ }^{172}$

The following phrase which comes from his later writings and which is aphoristic in nature is also based on an expression. It goes as follows: "To stay calm; to stay far away from what passion desires; to know the current and therefore to swim against the current; to swim against the current just because you feel like being carried along." [Ruhe zu bewahren; sehr weit abstehn von dem, was die Leidenschaft will; die Strömung kennen und deshalb gegen den Strom schwimmen; aus Lust am Getragensein gegen den Strom schwimmen.]. ${ }^{173}$

The fixed idiomatic expression "to swim against the current" [gegen den Strom schwimmen] is so to speak taken literally, developed as a metaphor and expanded to such an extent through an associative link into the 'current of emotions' that an illustration of psychic

172. Even imaginative concepts of a different kind can be developed in this fashion. Thus, The Metamorphosis is developed through many stages out of the concept vermin (see Hartmut Binder, Der Schaffensprozeß, pp. 145-154), cf. T 525, in a fragment of the Penal Colony: "He jumped up as if refreshed, when they spoke to him. With his hand on his heart, he said: 'I would be a scoundrel if I let that happen.' But then he took it literally and began to walk on all fours. [Wie erfrischt sprang er auf, als sie ihn ansprachen. Die Hand auf dem Herzen, sagte er: "Ich will ein Hundsfott sein, wenn ich das zulasse." Aber dann nahm er das wörtlich, und begann auf allen Vieren umherzulaufen.]

173. H 287. 
circumstances becomes possible. These circumstances presented themselves associatively during the transferal of the scenary into Kafka's inner world. The writer justifies his view to do justice to the idiom, thereby going against the commonly accepted view: he uses an argument which, according to normal common sense, would rather encourage one to avoid the current.

In the first illustration he reasons, as elsewhere, ${ }^{174}$ by means of a pun which is based on two terms related by the same root. The syntactically parallel conclusion heightens his interpretation of the idiom in that now the reason for why he wants to go against the current is precisely the reason for going with the current. The joy of following one's own passion is used to counter that. The text therefore acquires this surprising punch line in that a type of behaviour which is normally considered as reasonable is twice turned into its opposite.

It is a peculiarity of expressions which originate in semantic shifts that the levels of meaning and image can come together in a particular way. Thus they function together even with a different meaning. For example, the formulation "to turn black before one's eyes" [schwarz vor den Augen werden] makes sense even literally because it can indeed happen that the human field of vision changes in this way. But, of course, normally this indicates the beginning of unconsciousness in that the effect of a process stands metonymically for the whole.

Kafka uses the expression with a significant change: in America the head waiter holds so firmly onto Karl Roßmann's arms that this creates "darkness before Karl's eyes" [ein Dunkel vor Karls Augen]. And Hermann Kafka's brutal sexual admonitions have such an effect on his son that everything "becomes a little foggy" [ein wenig nebelhaft] before his eyes. This last expression characterizes at the same time a typical reflective state on the part of the writer which, in other places, is described by the term 'foggy consciousness'. ${ }^{175}$

174. See Richard T. Gray, Constructive Deconstructions. Kafka's Aphorisms: Literary Tradition and Literary Transformation (Tübingen, 1987), pp. 242-244.

175. A 236 and H 214, cf. T 724 and F 135. 
What is obvious in such cases in which the phrase does not appear as a thought or conversational expression of fictive characters is Kafka's attempt to render more difficult or indeed to block entirely the inscribed meaning of the traditional linguistic sequence. On the one hand, he thus counters the reproach that the power and originality of his prose is affected by the use of worn out word husks. On the other hand, he awakens the reader's attention through these changes. Now the reader does not experience the cliche-like nature of these forms and actually needs to picture metaphorically the particular expression in order to prove whether he has understood correctly or not.

If they function as narrative kernels, sayings too can become the starting points for literary texts. Kafka either transposes them directly into situationally determined narrative constructions ${ }^{176}$ or he lets the expressions carry him on freely to further narrative development. To further elaborate on this: since a fainting spell, as we say, comes over one [anwandelt], befalls one [überkommt], or engulfs one [umfängt], ${ }^{17}$ it could not but happen that these image-laden and nearly personified verbs inspired Kafka's powerful imagination to literary creation. This is particularly so because he himself had intimate experience in this area which he needed to come to terms with. ${ }^{178}$

176. For instance, $\mathrm{H}$ 387: "A straw? Many a person holds himself above water by hanging on to a thin line drawn by a pencil. Hanging on? A drowned man who dreams of being saved." [Ein Strohhalm? Mancher halt sich an einem Bleistiftstrich uber Wasser. Hält sich? Traumt als Ertrunkener von einer Rettung]. Replacing the straw by means of a pencil line, which is formed in similar fashion and, as the writer believes, gives comparably less support, the expression "to hang on to a straw" [sich an einen Strohhalm klammem] is transposed into the literary domain. The formulation attempts to express that this momentary phase of productivity does not represent a true escape from existing problems. $\mathrm{Cf}$. $\mathrm{Br} 374$.

177. Wörter und Wendungen. Wörterbuch zum deutschen Sprachgebrauch, edited by Dr. Erhard Agricola with the assistance of Herbert Gröner and Ruth Küfner (Müchen, 1970), p. 424.

178. Cf. T 286, 247 and 575 . 
For example, in the introduction to a small fragment a personified fainting spell walks into the room "like a large woman in a long flowing dress and a broad hat decorated with feathers" [als große Dame mit lang fließendem Kleid und breitem, mit Federn geschmücktem Hut]. She is fully capable of conquering the first person narrator's heart. But she does not exactly walk into the room: she leisurely strolls in and, continuing the same noble movement, she removes long, old fencing gloves and is ready to come over him, all the while bemoaning the cold rejection of her opponent. He, in turn, lying deep in his armchair, imagines the steps leading up to his apartment as a tireless, hopping wave-like movement. Clearly, this is a disturbance of perception which precedes the disappearance of consciousness, something that the narrator perceived about himself upon coming up the stairs. When the visitor addresses him "with a wink of the eye" [augenzwinkernd], it seems to him as if he were a sparrow who is jumping up and down on the steps and ruffling his feathers. This is another symbolic representation of the fainting spell which is about to overcome him. It is a metaphorization of the feeling of discomforture that he has on his very skin, which can accompany the onset of a nervous breakdown. ${ }^{179}$

Another narrative fragment begins with a "normal day" [ein gewöhnlicher Tag] which "bares its teeth" [die Zähne zeigt] to the main character. Thus this day becomes the cause of an event which confronts the main charcter in a threatening manner. Made concrete in this fashion, the teeth are standing around, each isolated from the other, with no direct contact (obviously the saying "to grin and bear it" [die Zähne zusammenbeißen] also plays a role in the composition). But in an incomprehensible fashion they are hanging onto the person opposite while this person is incapable of doing likewise. ${ }^{180}$ At the same time, Kafka uses the expression "to bite one's lips" [sich auf die Lippen beißen] which is based on the same type of image. This expression occurs in his work repeatedly ${ }^{181}$ and represents disappointment and

179. H $59 f$.

180. H 329 .

181. Cf. Hartmut Binder, Kafka in neuer Sicht, p. 185f. 
anger. Kafka uses the metaphorical dimension of this expression as the imagistic basis for an aphorism which, in the form of a metonymy, considers the effect of sudden inner experiences on the organs of speech. $^{182}$

A final example is the saying "to support (or bury) one's head in one's hands" [den Kopf in die Hănde stützen (oder vergraben)] which Kafka uses in his writing in three different ways. In a little fragment it appears in the narration as a semantic shift whose meaning is further elaborated on by the narrator: "I don't want to see anyone, I don't want to be disturbed by the sight of anyone. My desk, that is my place, my head in my hands, that's my posture. [Ich will niemanden sehn, ich will mich durch keinen Anblick verwirren lassen, beim Schreibtisch, das ist mein Platz, den Kopf in meinen Händen, das ist meine Haltung.]. ${ }^{183}$

Precisely this situation appears as the subject of one of Kafka's drawings, which probably originated in connection with his writing of The Trial. It depicts a figure leaning far over a desktop, its head buried deep in its hands which are lying on the table. ${ }^{184}$ Finally the expression is used in a different form in a kind of meditation: Kafka replaces the visible head of a narratively developed figure with its intellect. This intellect is personified as part of a gestural context and wins a metaphorical life of its own by being developed further in a playful manner. ${ }^{185}$

182. H 76.

183. H 233.

184. Cf. the illustration in Klaus Wagenbach, Franz Kafka. Bilder aus seinem Leben (Berlin, 1983), p. 144.

185. H 272. 
Such spinning out of sayings and expressions should not be characterized as grotesque, a prejudicially laden term, ${ }^{186}$ because the characteristics associated with the grotesque such as exaggeration, distortion, and the sudden combination of incompatible elements do not at all characterize Kafka's symbolic representations. It is also not permissible, since there is no proof, that studies refer to such representations as dream-like. ${ }^{187}$ However, it must be admitted, that the dream can visualize imaginative relationships as does a rebus, that its techniques for arranging obscure imaginative contents as a sequence of events have had an effect on stories like $A$ Country Doctor. ${ }^{188}$

Yet it cannot be substantiated that Kafka's technique of taking literally metaphorical commonplaces and of elaborating on them symbolizes at the same time repressed feelings as they are supposed to come to light in psychoanalytical treatment. Edward Timms rightly points out that the pigsty mentioned in A Country Doctor, out of which a beastly stable boy crawls, is characterized through associations that are related to sayings on the subject of pigs. These may have induced the author to develop the narration scenically. But it makes no sense that one has to resort to the teachings of Freud in order to explain this technique. Kafka's father alone provided him with pertinent linguistic material. Not only did he call the family cook 'beast' but he also summed up his relationship to an orphaned niece in his care by a phrase

186. See Norbert Kassel, Das Groteske bei Franz Kafka (München, 1969), pp. 120-122, in contradiction to his own definition of the grotesque (p. 26). Without mentioning Gunther Anders, who was the first to point out that Kafka used metaphorical elements in their literal meaning (Kafka Pro und Contra, Munchen, 1951, pp. 39-44), Kassel too maintains a similar usage of sayings, yet does not give one single proof.

187. See A. P. Foulkes, The Reluctant Pessimist. A Study of Franz Kafka (The Hague/Paris, 1967), pp. 63-76.

188. The sudden and unmediated changes of place as well as the empirically improbable developments in perception and the merging of various processes belong to this category. 
which became a 'classic' in the sense that it was quoted repeatedly by his children: "The blessed little creature left a real pigsty behind for me" [Die Gottselige hat mir viel Schweinerei hinterlassen]. ${ }^{189}$

A writer like Kafka noting down the metaphor "I won't anchor here" [hier ankere ich nicht] was able to imagine the implicit image so intensely (even though it was weakened through frequent common usage) that he saw the very ship, as well as the surging flood of water. Such a writer did not need to dream nor to visualize his suppressed sexuality like an avid student of Freud, in order to create the admittedly wilful metaphors and narrative constructs which are so typical of both his life and literary works.

It is enough to stress his very extraordinary faculty of imagination which many of his friends had noticed as well. Max Brod describes it as a particular manner of "fairy tale like inventiveness and spinning out of the fable" [märchenhafter Erfindung und Fortspinnung der Fabel], as well as an ability to see the common in a new way. This also includes the ability to perceive the more or less faded visual content of sayings and expressions. The fact that this required the ability to move freely and associatively back and forth between different, and even irreconciliable events, was stressed by Kafka himself. ${ }^{190}$

The original title of this article by Hartmut Binder is "Redensarten und Redewendungen bei Kafka."

189. H 194, cf. 172, Br 396 and Edward Timms, "Kafka's Expanded Metaphors. A Freudian Approach to Ein Landarzt," in Path and Labyrinths. Nine Papers Read at the Franz Kafka Symposium Held at the Institute of Germanic Studies on 20 and 21 October 1983 (London, 1985), p. $72 f$.

190. H 98. 